\title{
Tunisia: 2008 Article IV Consultation-Staff Report; Public Information Notice on the Executive Board Discussion; and Statement by the Executive Director for Tunisia
}

Under Article IV of the IMF's Articles of Agreement, the IMF holds bilateral discussions with members, usually every year. In the context of the 2008 Article IV consultation with Tunisia, the following documents have been released and are included in this package:

- $\quad$ The Staff Report for the 2008 Article IV Consultation, prepared by a staff team of the IMF, following discussions that ended on June 9, 2008, with the officials of Tunisia on economic developments and policies. Based on information available at the time of these discussions, the staff report was completed on July 21, 2008. The views expressed in the staff report are those of the staff team and do not necessarily reflect the views of the Executive Board of the IMF.

- $\quad$ A Public Information Notice (PIN) summarizing the views of the Executive Board as expressed during its August 6, 2008 discussion of the staff report that concluded the Article IV consultation.

- $\quad$ A statement by the Executive Director for Tunisia.

The policy of publication of staff reports and other documents allows for the deletion of market-sensitive information.

Copies of this report are available to the public from

International Monetary Fund • Publication Services $70019^{\text {th }}$ Street, N.W. • Washington, D.C. 20431

Telephone: (202) 623-7430 • Telefax: (202) 623-7201

E-mail: publications@imf.org Internet: http://www.imf.org

Price: $\$ 18.00$ a copy

\section{International Monetary Fund Washington, D.C.}





\title{
INTERNATIONAL MONETARY FUND
}

TUNISIA

\section{Article IV Consultation}

\author{
Prepared by the Middle East and Central Asia Department \\ Approved by Amor Tahari and Anthony Boote
}

July 21, 2008

- $\quad$ Discussions took place May 27 to June 9, 2008, in Tunis. The mission comprised

Mr. Senhadji (head), Ms. Simard, and Messrs. Loko and Saadi Sedik (all MCD). Mr. Rouai (OED) joined the mission.

- $\quad$ The mission met with Governor Baccar, Minister of Finance Kechiche, Minister of Economic Development and International Cooperation Jouini; other ministers and government officials; and private sector and labor representatives.

- $\quad$ Tunisia continues its close dialogue with the Fund while retaining full ownership of its economic program. The previous consultation was concluded on August 3, 2007. The staff report and PIN are available at http://www.imf.org/external/pubs/cat/longres.cfm?sk=21302.0

- $\quad$ The de facto exchange rate regime will be reclassified from managed float to a conventional peg to a composite.

- $\quad$ Tunisia accepted the obligations of Article VIII, sections 2, 3, and 4 in 1993. It subscribed to SDDS in June 2001. The timeliness and coverage of macroeconomic data are generally adequate for surveillance.

- The authorities are expected to continue publishing all documents related to the Article IV consultation. Outreach efforts included a seminar on estimation methodologies of the equilibrium real exchange rate and a press release at the end of the mission. 


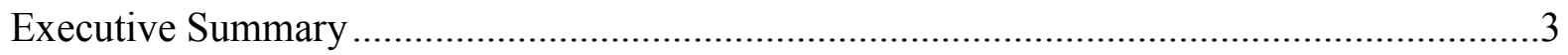

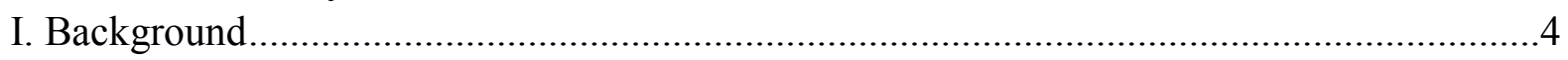

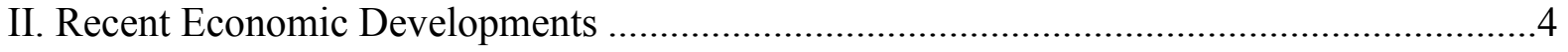

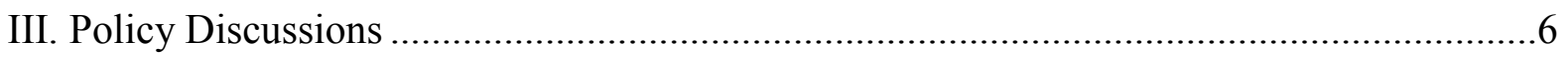

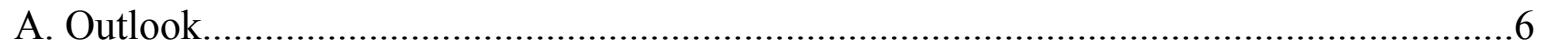

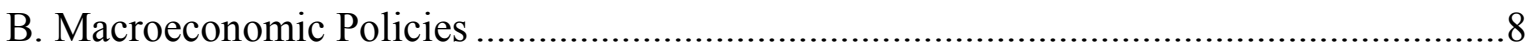

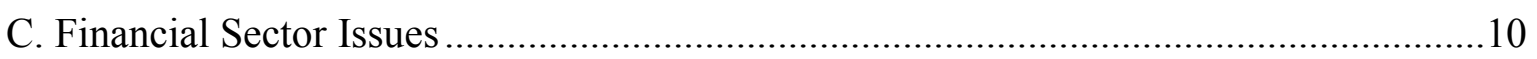

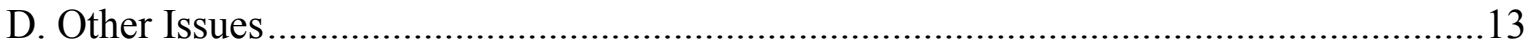

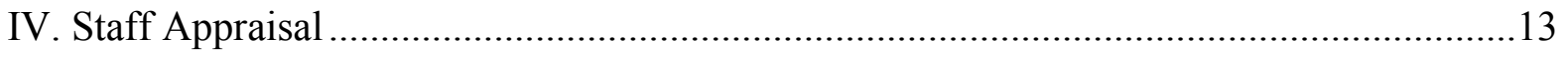

Boxes

1. Impact of the Global Financial Crisis on Tunisia ............................................................. 7

2. An Assessment of the Exchange Rate Level ........................................................... 11

Figures

1. External Debt Sustainability: Bound Tests .............................................................23

2. Public Debt Sustainability: Bound Tests ..................................................................25

Tables

1. Selected Economic and Financial Indicators, 2005-13 ..............................................16

2. Balance of Payments, 2005-13 .................................................................................... 17

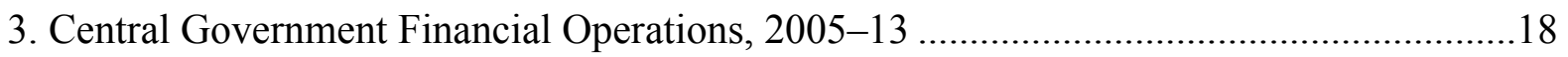

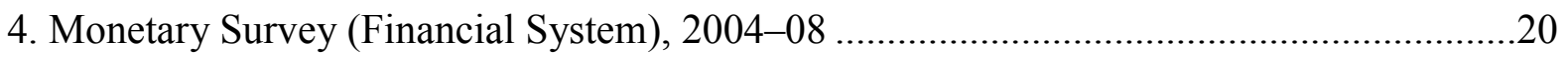

5. Medium-Term Growth Scenario, 2005-13 ...............................................................21

6. External Debt Sustainability Framework, 2003-13 …...............................................22

7. Public Debt Sustainability Framework, 2003-13 ........................................................24 


\section{EXECUTIVE SUMMARY}

\section{Background}

Sound economic policies and a pragmatic approach to structural reforms continue to bear fruit, as evidenced by strong growth and improved social indicators. However, important challenges remain. Unemployment, particularly among the youth, is still relatively high and an increasing number of university graduates are seeking jobs. The immediate challenge is to limit the effect from rising international fuel and food prices, slower global growth, and tighter international credit markets. Growth accelerated to 6.3 percent in 2007 and is likely to remain above 5 percent this year. However, inflation picked up and total food and fuel subsidies (direct and indirect) for 2008 are projected at 7.3 percent of GDP. Discussions centered on controlling inflation, maintaining fiscal sustainability, and promoting growth.

\section{Authorities' Views}

- Despite a significant increase in fuel and food subsidies, the authorities intend to maintain the overall fiscal deficit within the target of 3 percent of GDP owing to strong revenue, notably from the hydrocarbon sector. The authorities remain committed to fiscal consolidation, including the rationalization of subsidies over the medium term. Social stability considerations will determine the speed of reform.

- Monetary policy has turned restrictive since mid-2007 to curb inflation and additional policy instruments are being developed to better control excess liquidity. However, the Central Bank of Tunisia (BCT) has refrained from increasing its policy interest rate for fear of weakening growth.

- The quality of banks' balance sheet continues to improve and the authorities recognize that further strengthening of the banking sector remains a high priority.

\section{Staff Recommendations}

The staff broadly supports the authorities' macroeconomic policy stance and urges them to pursue the necessary reforms to preserve macroeconomic stability, enhance the economy's resilience, and promote growth and employment. In particular:

- The current subsidy system needs to be replaced by a more targeted safety net over the medium term in order to maintain fiscal sustainability, decrease the country's vulnerability to shocks, and create the necessary fiscal space for additional social and infrastructure spending.

- The BCT should stand ready to increase its policy interest rate if inflationary pressures intensify given that macroeconomic stability is a prerequisite to strong and sustained growth. There is no clear evidence of significant exchange rate misalignment and the authorities' policies are consistent with external stability.

- The mission encourages the authorities to continue enhancing the banking sector's efficiency and resilience in view of the gradual opening of the capital account. 


\section{BACKGROUND}

1. Sound economic policies underpinned by an outward-oriented reform strategy allowed Tunisia to achieve strong growth and improve its social indicators. Real GDP growth averaged 5 percent a year during the past decade, real GDP per capita increased by 45 percent between 1997 and 2007, average inflation was at 3 percent, and the external and fiscal positions have strengthened.

2. However, important challenges lie ahead. The authorities' major preoccupation that has shaped their medium-term strategy is how to reduce the still relatively high unemployment rate-14.1 percent for the active population in 2007 and significantly higher among the youth — while creating enough jobs for the fast-growing number of university graduates. The immediate challenge is to limit the macroeconomic impact from rising international fuel and food prices and the global financial turmoil. Against this backdrop, the 2008 consultation discussions focused on potential risks to the short-term outlook and the necessary policies to further reduce Tunisia's vulnerabilities and ensure high and sustained growth.

\section{RECENT ECONOMIC DEVELOPMENTS}

\section{Tunisia has so far weathered relatively well the difficult international environment:}

- $\quad$ Real GDP growth accelerated from 5.5 percent in 2006 to 6.3 percent in 2007, underpinned by strong performance of agriculture, energy, manufacturing, and the services sectors. On the demand side, vigorous exports and investment powered the growth acceleration. Economic growth slowed to 5.8 percent in the first quarter of 2008 but still remained above trend. The slowdown is primarily due to the decline in production of hydrocarbons on account of temporary technical difficulties, and the economic slowdown in the European Union.

- Inflation has picked up, due mainly to rising international fuel and food prices and, to a lesser extent, growing liquidity in the banking system reflecting increasing foreign direct investment (FDI). Year-onyear inflation reached 6 percent in April 2008 before pulling back to 4.9 percent in June. The BCT responded by tightening monetary policy starting in the second half of 2007, including by raising the required reserves ratio from $3 \frac{1}{2}$ percent to 5 percent at end-November 2007 and again to $7 \frac{1}{2}$ percent at

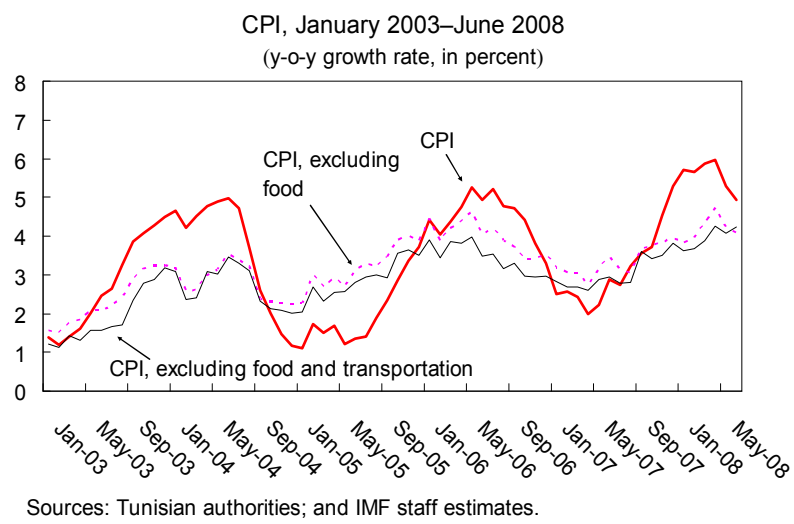


end-April 2008. However, the key policy interest rate has not changed since mid2006 and real interest rates declined in 2007 and have been hovering around zero in the first half of 2008. The nominal effective exchange rate depreciated by 2.8 percent in 2007, contributing somewhat to the inflation acceleration.

Interest Rates, Jan. 2004-March 2008

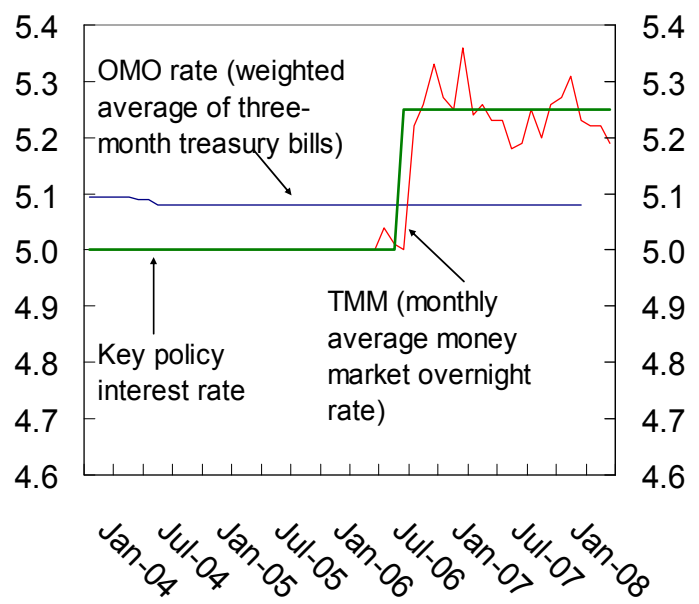

Exchange Rates, Jan. 2003-June 2008

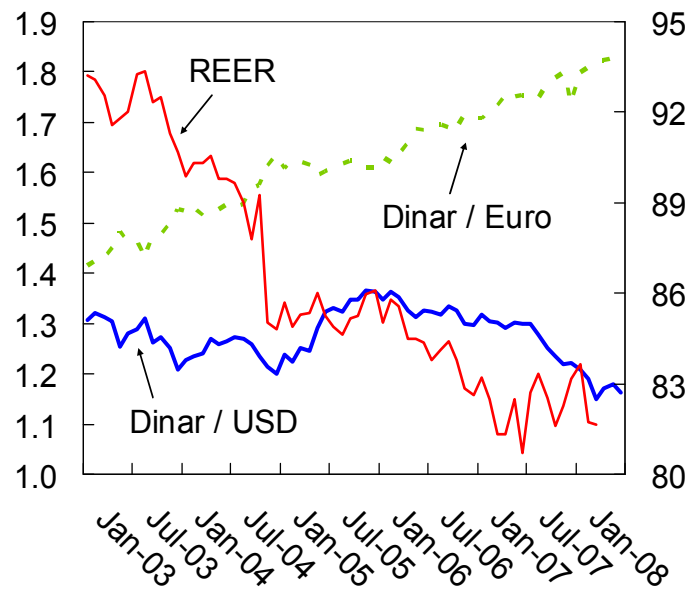

Sources: Tunisian authorities; and IMF staff estimates.

\section{The fiscal deficit was kept within the 2007 budget target of 3 percent of GDP.}

Revenue exceeded expectations owing mainly to stronger oil revenue-notably from oil companies' higher profits due to surging oil prices and increased domestic production. The additional revenue offset expenditure overruns mainly caused by rising direct food and fuel subsidies (2.5 percent of GDP in 2007). The favorable performance of tax revenues continued during the first four months of 2008. Fiscal consolidation and privatization

Public Debt, 2001-07 (In percent of GDP)

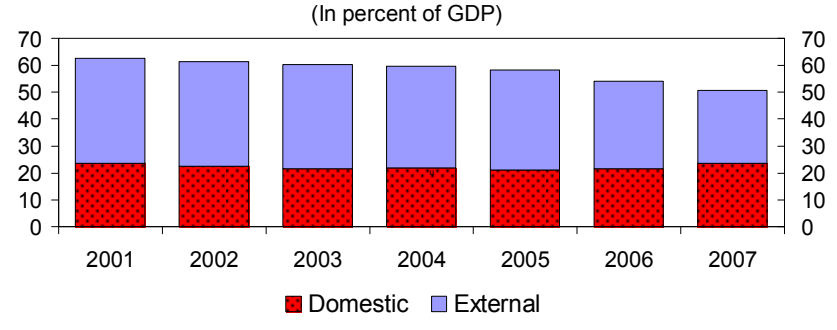

Sources: Tunisian authorities; and IMF staff estimates. receipts further reduced public debt-to-GDP ratio to about 51 percent at end-2007.

\section{The current account deficit widened from 2 percent of GDP in 2006 to}

2.6 percent of GDP in $\mathbf{2 0 0 7}$ due to declining terms of trade. This trend continued in the first quarter of 2008 on account of rising international fuel and food prices and buoyant imports of capital goods, and a drop in energy exports due to technical difficulties. With the significant increase in FDI inflows, international reserves amounted to over $\$ 81 / 2$ billion, largely sufficient to cover short-term liabilities. 


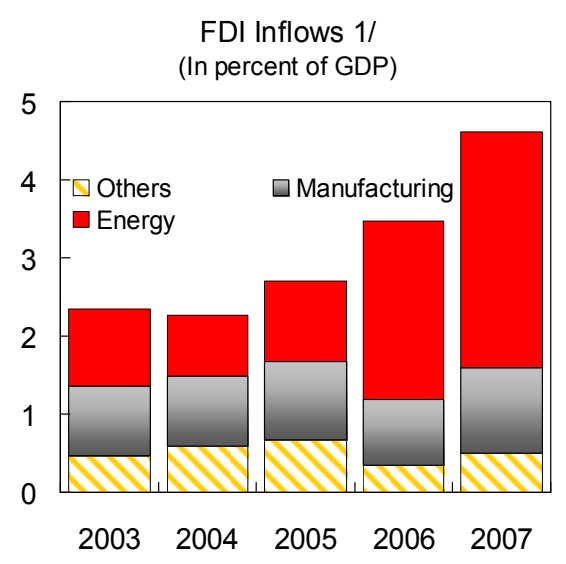

Sources: Tunisian authorities; and IMF staff estimates.

1/ Excluding $\$ 2.25$ billion in receipts from the partial privatization of Tunisie Telecom in 2006.

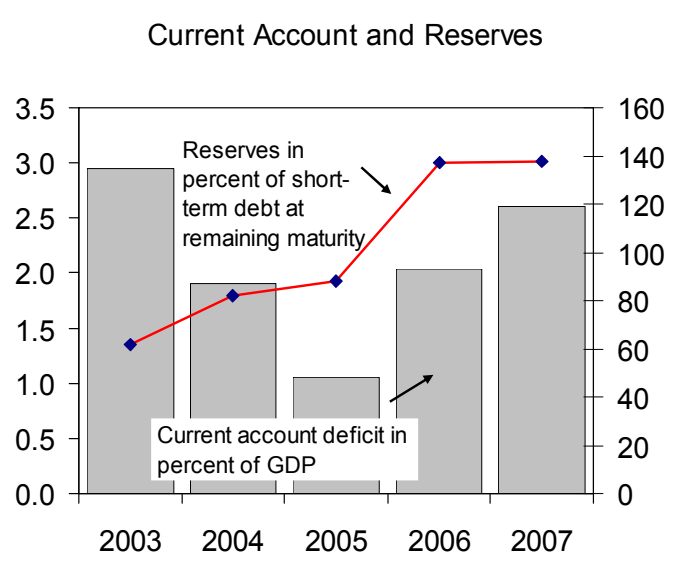

Sources: Tunisian authorities; and IMF staff estimates.

\section{Policy Discussions}

4. Discussions centered on (a) risks to the outlook from the global slowdown and record-high commodity prices; (b) the appropriate fiscal and monetary policy mix to contain inflation and sustain growth, including an assessment of external stability, and (c) the acceleration of structural reforms to consolidate Tunisia's financial and macroeconomic position and stimulate private investment.

\section{A. Outlook}

\section{The short-term outlook is encouraging despite the challenging international} environment. The global financial upheavals have thus far had only a limited impact on the Tunisian economy but could still affect it, mainly through the trade channel (Box 1). In 2008, real GDP growth is projected to decelerate moderately to 5.5 percent; inflation would remain about 5 percent if international prices taper off and monetary policy continues to be restrictive. High food prices and strong investments are expected to widen the current account deficit to 3.5 percent of GDP. The fiscal deficit is projected to remain at its 2008 budget target of 3 percent of GDP, owing to buoyant revenue, notably from the hydrocarbon sector.

\section{The increase in hydrocarbon production has cushioned the impact of surging international energy prices on the Tunisian economy. The trend deterioration in Tunisia's} energy trade balance has been reversed last year as

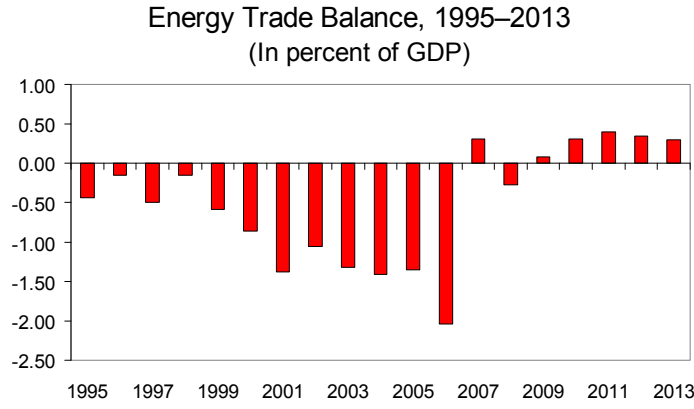

Sources: Tunisian authorities; and IMF staff estimates. 


\section{Box 1. Impact of the Global Financial Crisis on Tunisia}

The impact of the ongoing global financial market turmoil on Tunisia has been limited so far, given its relatively strong macroeconomic position and no direct exposure to the U.S. subprime market. Some indirect effect could come from a higher sovereign spread, although Tunisia has no pressing need to issue debt abroad.

\section{Tunisia's macroeconomic and financial position strengthened substantially over the past decade but vulnerabilities remain:}

Public sector vulnerabilities. Fiscal consolidation and privatization receipts helped put public debt on a steady declining path, although it remains Emerging Market Bond Spreads (In basis points) (January 2007-April 2008) relatively high by emerging economies standards. The share of public debt exposed to exchange rate and rollover risks has declined significantly in recent years, owing to efficient debt management. Government-guaranteed loans were estimated at about 11 percent of GDP at end-2007 but they have not generated any significant budgetary outlays so far. Stress tests (Tables 6 and 7, Figures 1 and 2) highlight exchange rate and lower growth risks.

External sector vulnerabilities. External debt declined but remains relatively high at about 55 percent of GDP at end-2007. Risks are contained as: (a) almost 80 percent of the external debt stock is in long-term liabilities, 70 percent of which is owed to multilateral and bilateral creditors, implying limited rollover risks;

(b) about 75 percent of the debt is contracted in fixed interest rates with little interest rate risk; and (c) the stock of reserves more than fully covers all short-term liabilities in 2007.

Financial sector vulnerabilities.

Financial sector risks, although not systemic in the current environment of relatively closed capital account, could be magnified as the economy continues Selected Vulnerability Indicators

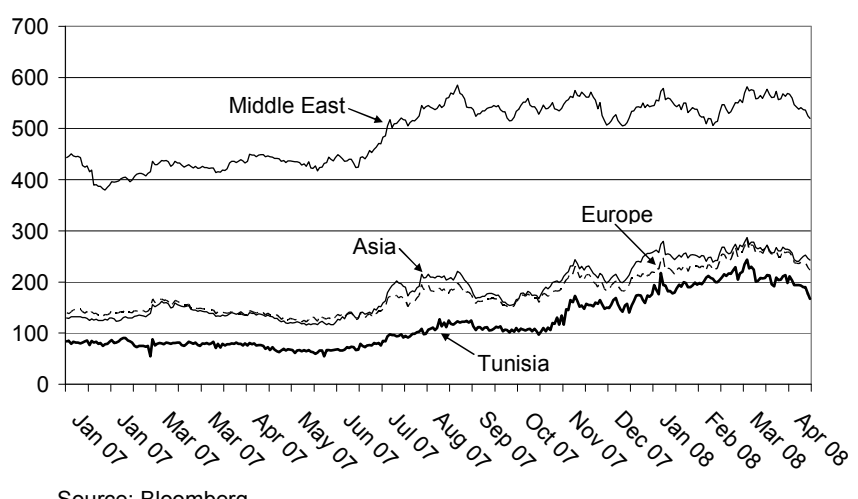
Source: Bloomberg. to integrate the world economy. While nonperforming loans have declined significantly over the past few years owing to strengthened regulatory and supervisory frameworks and healthy economic growth, they still remain high. As a result, profitability is low and capital adequacy, while above the regulatory minimum, is below the average level in other emerging markets. 
a result of high energy prices and a positive supply response. The small energy trade surplus is likely to last for the next five years since energy prices are projected to remain high over the medium term but it would eventually turn negative in a not too distant future given Tunisia's limited hydrocarbon reserves and growing energy consumption.

\section{The main risks to the outlook are essentially related to the international} environment and developments in the hydrocarbon sector. On the downside, economic activity could record a more pronounced slowdown if growth in the EU were to decelerate further or if the technical problems that have hampered domestic hydrocarbon production in the first quarter of 2008 are not rapidly resolved. Furthermore, rising energy and food prices and the growing liquidity resulting from more sizeable capital inflows (particularly FDI) could complicate monetary policy and fuel inflationary pressures. On the upside, the planned FDI-financed large scale projects, mainly in real estate, could further boost growth, although there is considerable uncertainty about the effective amount that would be invested since these projects will be carried out in several phases and completion will depend on profitability. Two such projects, originating from countries in the Gulf region, have already begun and could attract up to $\$ 20$ billion in investment over the next 20 years.

8. The medium-term outlook remains favorable with growth projected at above 6 percent sustained by strong FDI. Prudent monetary and fiscal policies should bring inflation back to its historic range of 2-3 percent and maintain debt-to-GDP ratios on a downward trend.

Medium-Term Projections 2008-13

\begin{tabular}{lrrrrrr}
\hline & 2008 & 2009 & 2010 & 2011 & 2012 & 2013 \\
\hline Real GDP (annual percentage change) & 5.5 & 5.8 & 6.1 & 6.2 & 6.3 & 6.4 \\
CPI inflation (period average) & 5.1 & 4.5 & 3.5 & 3.2 & 2.9 & 2.7 \\
Current account balance (in percent of GDP) & -3.5 & -3.3 & -3.1 & -2.9 & -2.7 & -2.5 \\
Fiscal balance (in percent of GDP) & -3.0 & -2.9 & -2.8 & -2.7 & -2.6 & -2.5 \\
Public debt (in percent of GDP) & 47.0 & 46.0 & 44.3 & 42.5 & 41.7 & 40.8 \\
\hline
\end{tabular}

Sources: Tunisian authorities; and IMF staff estimates and projections.

\section{B. Macroeconomic Policies}

9. Discussions centered on the policy mix that would support growth while keeping inflation in check, preserving fiscal sustainability, and ensuring external stability in an environment of rising international fuel and food prices and excess liquidity. 


\section{Fiscal policy}

10. The authorities intend to maintain the fiscal deficit within the $\mathbf{2 0 0 8}$ budget target of 3 percent of GDP, without reducing public investment. Despite the sizeable increase in domestic prices of petroleum products (107.4 percent increase since 2003), rising international energy and food prices have increased subsidies significantly-direct and indirect fuel and food subsidies are estimated at 7.3 percent of GDP for 2008, with indirect subsidies accounting for 4.1 percent of GDP (assuming an average price of oil of $\$ 116.5 \mathrm{a}$ barrel). The authorities expect that the latter will be offset by increases in both tax and nontax revenues owing to three main factors: (a) higher hydrocarbon production; (b) sustained economic activity; and (c) enhanced efficiency of the tax administration.

\section{The authorities have reiterated their intention to persevere with fiscal} consolidation and further reduce public debt. They are well aware that petroleum reserves may prove insufficient to maintain the level of subsidies over the long term, particularly in light of the need to free up fiscal space to address growing demographic pressures. The government intends to rationalize further current spending, including by phasing out subsidies for petroleum products by 2011 as envisaged in the $\mathrm{XI}^{\text {th }}$ Plan. With respect to food subsidies, the authorities have taken steps to ensure better control of expenditures and boost agricultural production. They are also planning their restructuring over the medium term. However, they underscored that social stability considerations will determine the speed of reforms.

\section{Reforms aimed at strengthening the efficiency of the tax and customs}

administration continue. Specifically, a new customs code was promulgated, a Large Taxpayer Unit was established, and the modernization of the IT system for the tax administration progresses with the development of e-filing.

\section{Monetary and exchange rate policy}

13. The authorities are mindful of the importance of curbing inflation. The BCT has so far contained inflation mainly through open market operations, liquidity auctions, and the required reserves ratio. It is considering remunerating required reserves so as to mitigate the cost imposed on banks. So far, the BCT has been reluctant to raise its key policy interest rate for fear of weakening growth and employment.

\section{The BCT is developing additional monetary policy instruments to address} persistent excess liquidity. As a result of the BCT's persistent liquidity mopping operations, its stock of treasury securities has dwindled since mid-2006, thereby limiting its ability to manage liquidity going forward. Indeed, since September 2007, the BCT relied mainly on 
deposit auctions and required reserves ratio to control liquidity. In view of increasing excess liquidity, the BCT is considering expanding the range of instruments for liquidity management, including issuing BCT debt certificates and implementing mechanisms for foreign exchange swaps.

\section{The move toward an inflation-targeting} framework progresses. The $\mathrm{BCT}$ is reinforcing its human resources and developing its analytical
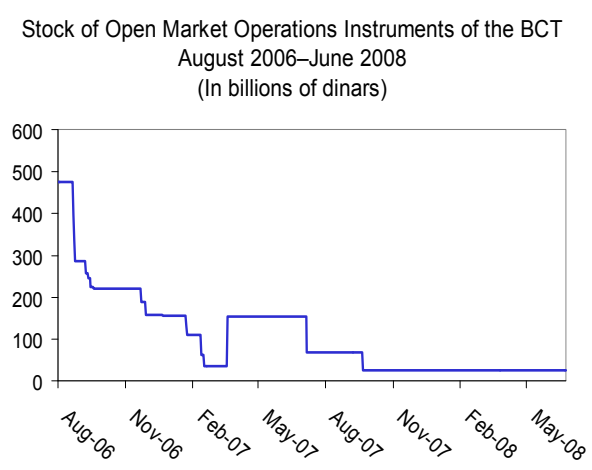

Sources: Tunisian authorities. capacity. It relies increasingly on indirect monetary instruments within the current broad money targeting framework and a de facto pegged exchange rate. While the latter limits the effectiveness of monetary policy, the BCT retains largely control over monetary policy because of the still relatively closed capital account. The BCT is gradually decreasing its interventions in the foreign exchange market, consistent with its medium-term objective of a floating exchange rate. Its interventions have declined by more than half, from 17.3 percent of the total volume of transactions on the spot market in 2003 to 7 percent in the first five months of 2008, and most of these interventions are for liquidity management purposes. The BCT's operations on the foreign exchange market are largely sterilized and essentially represent its transactions on behalf of the government. The BCT also plans to eventually eliminate its current practice of posting the exchange rate daily. Regarding the indexation of banks' balance sheet to the money market interest rate, the authorities concur that it hampers the development of the money market, restrict the flexibility of monetary policy, and shift interest rate risk to consumers and investors, who are least equipped to manage it.

16. The exchange rate is broadly aligned with its fundamentals and the authorities' policies are consistent with external stability. The depreciation in the real effective exchange rate (REER) over the recent years has been driven by persistent negative terms of trade shocks and greater trade openness, particularly in the context of the association agreement with the EU (Box 2).

\section{Financial Sector Issues}

\section{A sound banking system is crucial for enhancing the economy's resilience and} achieving high and sustained growth. Thus, the authorities place a high priority on further strengthening the banking sector. Bank performance improved significantly in 2007: banking activity and profitability increased; the ratio of nonperforming loans (NPLs) to total loans declined, largely accounted for by the proactive management of such claims; and the provisioning ratio improved. 


\section{Box 2. An Assessment of the Exchange Rate Level}

Results using the CGER methodology suggest on balance that the current level of the real exchange rate is broadly in line with fundamentals. ${ }^{1}$

- Using CGER's panel coefficient estimates for the macroeconomic balance (MB) approach yields a relatively small overvaluation of the REER (about 3 percent).

- The external sustainability (ES) approach shows an undervaluation of 11.7 percent.

- Tunisia is not included in the CGER sample for

Exchange Rate Assessment Using CGER Panel Estimates

(In percent)

\begin{tabular}{lccc}
\hline & $\begin{array}{c}\text { Underlying } \\
\text { CA balance }\end{array}$ & $\begin{array}{c}\text { CA } \\
\text { Norm }\end{array}$ & $\begin{array}{c}\text { REER } \\
\text { Misalignment }\end{array}$ \\
\hline MB approach & -2.6 & -1.6 & 2.7 \\
ES approach & -2.6 & -7.6 & -11.7 \\
\hline
\end{tabular}

1/ Adjusted for exchange rate changes Overvaluation (+); undervaluation (-) the equilibrium real exchange rate (EREER) approach.

The MB and the ES estimates suffer from important shortcomings. In particular, the assessment using the MB approach is based on panel estimation, which does not control adequately for country specific factors, while the external sustainability approach requires estimating the "appropriate" net foreign asset position to be stabilized.

The CGER results above are complemented by a more refined analysis based on a country specific equilibrium REER relationship for Tunisia. There is a cointegration relationship between the REER, the labor productivity differential with respect to trading partners (prod), terms of trade $(t t)$, and the trade openness indicator (open): reer $=7.55+1.13$ prod $+0.46 t t-1.15$ open

$$
(-15.2)(-5.8)
$$

The estimated coefficients have the expected sign and are significant ( $t$-stats are in brackets). The results suggest a very small gap ( 0.5 percent) between the REER and its equilibrium level. Therefore, the depreciation in the REER over the past five years is an equilibrium phenomenon, linked to persistent negative terms of trade shocks and greater trade openness.
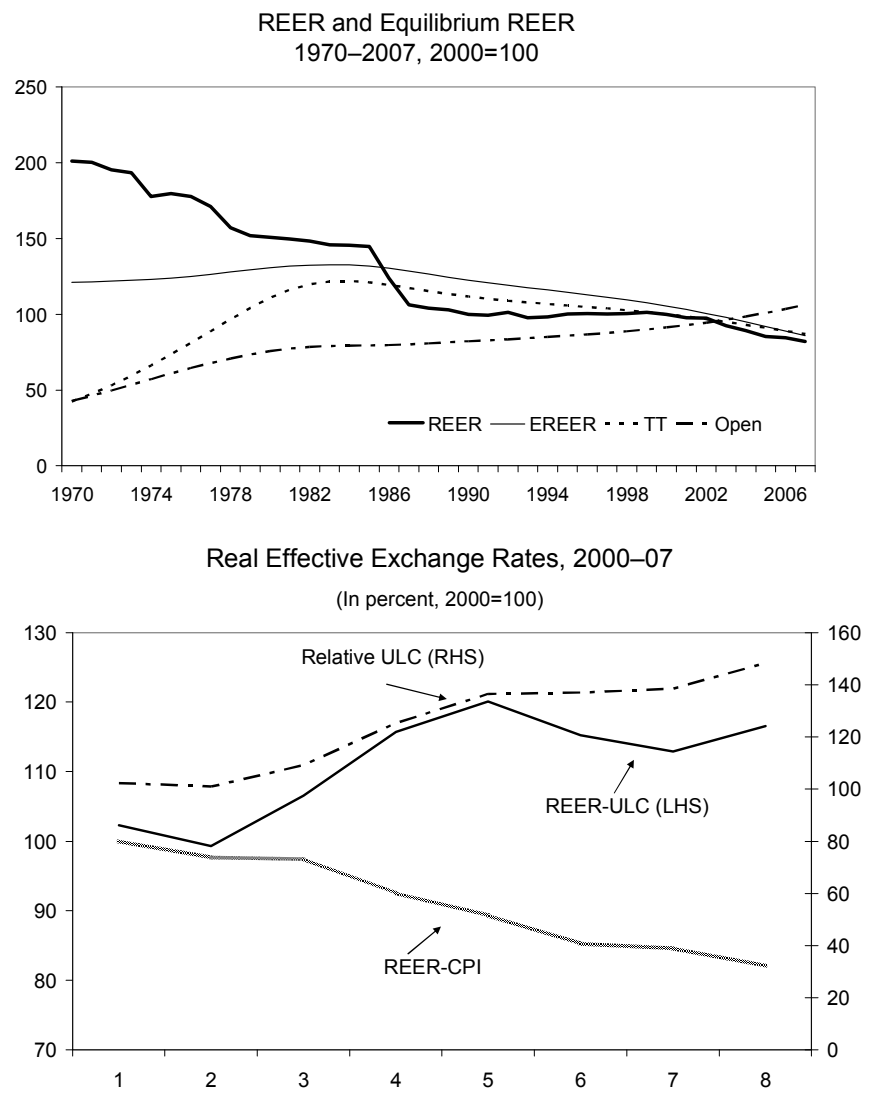

Competitiveness indicators do not show evidence of any significant misalignment either. The ULC-based REER has appreciated in the recent period, driven mostly by relatively high unit labor costs in Tunisia. Moreover, the economy is characterized by declining market shares for exports, and structural trade and current account deficits—respectively, 9.2 percent and 2.9 percent of GDP for the 2000-07 average.

1/ The CGER methodology can be found at this link: (www.imf.org/external/pp/longres.aspx?id=3957). 
Commercial Banks Soundness Indicators

\begin{tabular}{lrrrrr}
\hline & 2003 & 2004 & 2005 & 2006 & $2007^{1 /}$ \\
\hline Capital adequacy ratio & 9.3 & 11.6 & 12.4 & 11.3 & 11.0 \\
$\quad$ Private banks & 8.4 & 12.4 & 13.5 & 12.1 & 11.5 \\
$\quad$ Public banks & 10.8 & 10.1 & 10.0 & 9.3 & 10.0 \\
NPLs (percent of gross assets) & 24.0 & 23.7 & 20.9 & 19.0 & 17.3 \\
$\quad$ Private banks & 21.6 & 20.4 & 20.0 & 19.7 & 17.3 \\
Public banks & 26.7 & 27.4 & 22.1 & 19.7 & 17.3 \\
Provisions (percent of NPLs) & 43.1 & 45.8 & 47.4 & 49.2 & 53.8 \\
$\quad$ Private banks & 39.9 & 43.5 & 45.9 & 48.4 & 51.0 \\
$\quad$ Public banks & 46.2 & 47.6 & 49.1 & 50.2 & 56.9 \\
Return on assets & 0.6 & 0.4 & 0.5 & 0.7 & 0.9 \\
Return on equity & 7.6 & 5.1 & 6.5 & 7.7 & 9.0 \\
\hline
\end{tabular}

Source: Tunisian authorities.

1/ Preliminary.

18. The still relatively high NPLs ratio hampers growth through higher financing costs of investments and delays the full integration of the domestic financial system to international financial markets. The authorities are confident that they will meet their dual objectives for 2009 of reducing the NPLs ratio to 15 percent and raising the ratio of provisions to NPLs to 70 percent. Regarding potential risks associated with large-scale projects financed by foreign investors, the authorities indicated that the implementation of these projects carry little risk for the banking system's soundness since about 90 percent of the financing will be from abroad. However, once built, these projects will be sold to domestic and foreign investors who will likely need at least partial domestic financing. The authorities will be monitoring closely developments in the banking sector and have already tightened prudential regulation on the purchase of real estate. In particular, they noted that long-term loans extended to the acquisition of real estate units associated with these projects will need to be backed by assets of same duration.

19. The reform of the banking sector is continuing with the recent privatization of another bank - Banque Tuniso-Koweitienne - the improvement in quality of service, and the preparations for Basel II. In addition, a number of steps have been taken to give banks greater flexibility and broaden the scope of their activity. In particular, the requirement that banks transfer their end-of-day foreign exchange balances to the BCT (nivellement) should be abolished over the next few months. There are plans to delegate to banks the authority to quote and execute transactions involving exchange rate and interest rate hedging instruments, as well as to lengthen the maturity of such instruments. Listed credit institutions are no 
longer limited by a cap on their foreign borrowing. However, the Tunisian banking sectorwith about twenty banks for a relatively small market—remains fragmented and the small size of banks impedes the exploitation of important economies of scale.

\section{Other Issues}

20. The Tunisian economy continues to deepen its global and regional integration. Tunisia is pursuing trade liberalization, particularly in the context of the association agreement with the EU that culminated in free trade in industrial products in 2008. Negotiations focusing on agricultural goods and on services are in progress. Tunisia is also further streamlining tariffs under the Most Favored Nation regime, having decreased the average tariff rate from 28.8 percent in 2007 to 25.3 percent in 2008. Intra-regional tradealthough still relatively low-is benefiting from the Agadir Agreement, entered into force in March 2007 to liberalize trade between member countries (Egypt, Jordan, Morocco, and Tunisia). Tunisia is also actively engaged in regional integration; it organized the third annual conference on this issue in November 2007, focusing on the role of the private sector in regional integration.

21. Capital account liberalization advances gradually. Recent measures include the easing of constraints affecting investment outflows from Tunisia abroad and participations of residents to capital of nonresident corporations based in Tunisia. Furthermore, nonresidents investing in industrial and tourism zones no longer need an exchange authorization.

\section{Tunisia has recently made significant progress in improving the business}

climate. The new law on economic initiative, promulgated in December 2007, is designed to foster business creation by simplifying administrative procedures, facilitating financing, and reducing the tax burden. In addition, customs formalities are being comprehensively streamlined, with the total holding period for merchandise being reduced from nine days in 2006 to approximately six days. The goal is to reach three days in 2009. Finally, recent advances in tax administration have improved the quality of services for taxpayers.

\section{The implementation of the Report on the Observance of Standards and Codes} on Anti Money Laundering/Combating the Financing of Terrorism (AML/CFT) progresses. Tunisia is pursuing its efforts to strengthen its AML/CFT system according to the recommendations of the Financial Action Task Force (FATF)'s report, with particular attention given to training in the financial sector. A follow-up assessment will take place during the Plenary Meeting of the Middle East \& North Africa FATF in April 2009.

\section{STAFF APPRAISAL}

\section{Tunisia's economy continues to demonstrate remarkable resilience but} important challenges lie ahead. The growth acceleration in 2007 is impressive and, if sustained, it could make a significant dent in the unemployment rate, which remains relatively high, especially among young people. The outlook remains favorable. Buoyant FDI 
should support growth but close monitoring of potential risks in the form of government contingent liabilities or credit risk for banks is warranted. This is particularly relevant for large real estate projects. However, near-term risks are mainly associated with the external environment and the immediate challenge is to limit the impact of rising international fuel and food prices in a way that does not erode Tunisia's medium-term macroeconomic position.

25. Staff endorses the authorities' decision to maintain the fiscal deficit within the 2008 budget target of 3 percent of GDP, which would likely entail additional adjustments in domestic petroleum prices and tight control over current spending, including the wage bill. Closer coordination with the central bank is advisable to allow a timely monetary policy response, if needed.

26. Medium-term fiscal sustainability will require reforming the subsidy system. The level of subsidies is not sustainable given Tunisia's limited hydrocarbon reserves and the persistently high fuel and food prices. While staff encourages the authorities to continue their policies for energy conservation and promotion of agricultural production, the current subsidy system needs to be replaced by a more targeted safety net over the medium term in order to maintain fiscal sustainability, decrease the country's vulnerability to shocks, and create the necessary fiscal space for additional social and infrastructure spending.

\section{The BCT's restrictive monetary policy stance has so far been broadly} appropriate, with inflation starting to decline. However, if inflationary pressures were to intensify, it would be necessary to raise the BCT's key policy interest rate-an instrument that has proven its effectiveness in the recent past—given that growth has still significant momentum. The mission supports the BCT's recent efforts to examine the various options for managing the structural surplus liquidity in the Tunisian financial system, including the option to issue central bank debt certificates.

28. Staff encourages the authorities to continue putting in place the building blocks for the planned inflation-targeting framework, including by deindexing banks' balance sheets to the money market interest rate, increasing exchange rate flexibility, deepening money and foreign exchange markets, and ensuring that the banking sector is prepared to manage greater exchange rate and interest rate risk. The BCT's effort to refine its forecasting tools so as to better anticipate inflationary pressures and take timely action should be intensified.

29. The exchange rate is broadly aligned with its fundamentals and the authorities' policies are consistent with external stability. The exchange rate policy should remain anchored by the authorities' medium-term objective of a floating exchange rate. Considering current global inflationary pressures, enhanced exchange rate flexibility could help reduce imported inflation. 
30. The balance sheet of the banking sector continues to strengthen, owing to the authorities' proactive policies and strong economic performance. Attaining or even surpassing the authorities' dual objective — of reducing the NPLs ratio to 15 percent and raising the ratio of provisions to NPLs to 70 percent - would further strengthen the banking system's resilience, particularly in light of the gradual opening of the capital account. Regarding market structure, further consolidation could reduce cost and improve productivity through economies of scale. Staff supports the authorities' objective of implementing the Basel II system by end-2009 and achieving full compliance with AML/CFT international standards over the medium term.

\section{The current financial crisis in the developed countries offers useful lessons} regarding banking system consolidation. In particular, it is important to continuously adapt the regulatory and supervisory frameworks to reflect financial sector developments, collect timely data for adequate supervision, and ensure that contingency plans are in place in case of a systemic failure of the financial system.

\section{Staff supports Tunisia's pragmatic approach to trade and financial integration.} The achievement of zero tariffs on industrial goods with the EU this year is an important milestone and Tunisia's active participation in the regional integration effort sponsored by the Fund is welcome. Further simplification and reduction of most-favored nation tariffs are needed in order to prevent trade diversion and enhance geographic diversification of trade. Staff supports the authorities' gradual approach to full convertibility of the dinar.

33. The business climate continues to improve. Further liberalization of the services sector and the ongoing reform of the tax and customs administrations should further promote domestic and foreign investment.

34. It is proposed that the next Article IV consultation be held on the standard 12 month cycle. 
Table 1. Selected Economic and Financial Indicators, 2005-13

\begin{tabular}{|c|c|c|c|c|c|c|c|c|c|}
\hline & \multirow[b]{2}{*}{2005} & \multirow[b]{2}{*}{2006} & \multirow{2}{*}{$\frac{\text { Est. }}{2007}$} & \multicolumn{6}{|c|}{ Projections } \\
\hline & & & & 2008 & 2009 & 2010 & 2011 & 2012 & 2013 \\
\hline \multicolumn{10}{|l|}{ Production and income (percent change) } \\
\hline Nominal GDP & 7.0 & 9.4 & 8.9 & 9.8 & 8.2 & 9.4 & 9.5 & 8.9 & 8.4 \\
\hline Real GDP & 4.0 & 5.5 & 6.3 & 5.5 & 5.8 & 6.1 & 6.2 & 6.3 & 6.4 \\
\hline GDP deflator & 2.9 & 3.7 & 2.4 & 4.1 & 2.3 & 3.1 & 3.1 & 2.4 & 1.9 \\
\hline Consumer price index (CPI), average & 2.0 & 4.5 & 3.1 & 5.1 & 4.5 & 3.5 & 3.2 & 2.9 & 2.7 \\
\hline Gross national savings (in percent of GDP) & 20.8 & 22.1 & 22.4 & 21.6 & 21.8 & 22.0 & 22.4 & 22.7 & 23.1 \\
\hline Gross investment (in percent of GDP) & 22.0 & 24.1 & 25.1 & 25.1 & 25.1 & 25.2 & 25.3 & 25.4 & 25.6 \\
\hline \multicolumn{10}{|l|}{ External sector (percent change) } \\
\hline Exports of goods, f.o.b. (in \$) & 8.3 & 9.7 & 30.4 & 29.9 & 13.7 & 11.7 & 13.4 & 14.3 & 15.3 \\
\hline Imports of goods, f.o.b. (in \$) & 2.9 & 12.7 & 28.0 & 29.1 & 12.8 & 10.7 & 12.3 & 13.2 & 14.0 \\
\hline Exports of goods, f.o.b. (volume) & 1.5 & 6.3 & 19.9 & 16.4 & 12.8 & 11.0 & 12.1 & 13.4 & 14.5 \\
\hline Import of goods, f.o.b. (volume) & -6.0 & 5.1 & 10.9 & 10.2 & 8.4 & 9.3 & 9.8 & 10.2 & 10.6 \\
\hline Trade balance (in percent of GDP) & -6.8 & -8.2 & -8.4 & -9.4 & -9.2 & -9.0 & -8.8 & -8.6 & -8.3 \\
\hline Current account, excluding grants (in percent of GDP) & -1.1 & -2.0 & -2.6 & -3.5 & -3.3 & -3.1 & -2.9 & -2.7 & -2.5 \\
\hline Foreign direct investment (percent of GDP) & 2.6 & 10.4 & 4.2 & 4.6 & 4.8 & 5.0 & 5.1 & 5.2 & 5.2 \\
\hline Terms of trade (deterioration -) & -2.5 & -3.7 & -5.4 & $\ldots$ & $\ldots$ & $\ldots$ & $\ldots$ & $\ldots$ & $\ldots$ \\
\hline Real effective exchange rate (depreciation -) 1/ & -4.6 & -0.8 & -2.9 & $\ldots$ & $\cdots$ & $\cdots$ & $\cdots$ & $\cdots$ & $\ldots$ \\
\hline \multicolumn{10}{|l|}{$\begin{array}{l}\text { Central government (percent of GDP, unless } \\
\text { otherwise indicated) } 2 /\end{array}$} \\
\hline Total revenue, excluding grants and privatization & 23.6 & 23.8 & 24.2 & 24.6 & 24.5 & 24.5 & 24.5 & 24.3 & 24.3 \\
\hline Total expenditure and net lending & 26.9 & 26.6 & 27.2 & 27.6 & 27.5 & 27.3 & 27.2 & 27.0 & 26.8 \\
\hline Central government balance, excluding grants and & & & & & & & & & \\
\hline privatization & -3.2 & -2.9 & -3.0 & -3.0 & -2.9 & -2.8 & -2.7 & -2.6 & -2.5 \\
\hline Central government balance, including grants, & & & & & & & & & \\
\hline excluding privatization & -3.0 & -2.7 & -2.9 & -2.7 & -2.7 & -2.6 & -2.5 & -2.5 & -2.4 \\
\hline Total government debt (foreign and domestic) & 58.3 & 53.9 & 50.9 & 47.0 & 46.0 & 44.3 & 42.5 & 41.7 & 40.8 \\
\hline Foreign currency public debt (percent of total debt) & 63.9 & 59.8 & 58.3 & 57.0 & 57.5 & 57.3 & 54.8 & 51.6 & 47.9 \\
\hline \multicolumn{10}{|l|}{ Money and credit (percent change) } \\
\hline Credit to the economy & 6.3 & 6.6 & 9.6 & 8.5 & $\ldots$ & $\ldots$ & $\ldots$ & $\ldots$ & $\ldots$ \\
\hline Broad money (M3) 3/ & 11.0 & 11.4 & 12.5 & 10.5 & $\ldots$ & $\ldots$ & $\ldots$ & $\ldots$ & $\ldots$ \\
\hline Velocity of circulation (GDP/M3, deposit money banks) & 1.8 & 1.8 & 1.8 & 1.8 & $\ldots$ & $\ldots$ & $\ldots$ & $\ldots$ & $\ldots$ \\
\hline Velocity of circulation (GDP/M3) & 1.6 & 1.6 & 1.5 & 1.5 & $\ldots$ & $\ldots$ & $\ldots$ & $\ldots$ & $\ldots$ \\
\hline Interest rate (money market rate, in percent, e.o.p) 4/ & 5.00 & 5.33 & 5.10 & 5.25 & $\cdots$ & $\ldots$ & $\cdots$ & $\cdots$ & $\cdots$ \\
\hline \multicolumn{10}{|l|}{ Official reserves } \\
\hline Gross official reserves ( $\$$ billions, e.o.p) & 4.4 & 6.8 & 7.9 & 8.9 & 10.2 & 11.8 & 13.4 & 15.4 & 17.5 \\
\hline In months of imports of goods and services, c.i.f. & 3.7 & 5.0 & 4.6 & 4.1 & 4.2 & 4.4 & 4.4 & 4.5 & 4.5 \\
\hline \multicolumn{10}{|l|}{ Total external debt } \\
\hline External debt ( $\$$ billions) & 18.1 & 18.5 & 20.2 & 20.8 & 21.8 & 23.0 & 23.9 & 25.0 & 25.9 \\
\hline External debt (in percent of GDP) & 65.4 & 58.3 & 54.9 & 51.8 & 51.2 & 49.9 & 47.5 & 45.6 & 43.6 \\
\hline Debt service ratio (percent of exports of GNFS) & 14.8 & 18.8 & 13.0 & 9.9 & 9.3 & 9.2 & 9.7 & 8.8 & 8.3 \\
\hline \multicolumn{10}{|l|}{ Financial market indicators } \\
\hline Stock market index 5/ & 1,615 & 2,331 & 2,614 & 3,041 & $\cdots$ & $\cdots$ & $\cdots$ & $\cdots$ & .. \\
\hline \multicolumn{10}{|l|}{ Memorandum items: } \\
\hline GDP at current prices (TD millions) & 37,664 & 41,211 & 44,861 & 49,277 & 53,303 & 58,323 & 63,891 & 69,551 & 75,412 \\
\hline GDP at current prices ( $\$$ billions) & 27.6 & 31.8 & 36.7 & 40.2 & 42.5 & 46.2 & 50.4 & 54.8 & 59.5 \\
\hline GDP per capita $(\$)$ & 2,754 & 3,137 & 3,594 & 3,878 & 4,055 & 4,342 & 4,677 & 5,024 & 5,386 \\
\hline Unemployment rate (in percent) & 14.2 & 14.3 & 14.1 & 14.0 & 13.8 & 13.6 & 13.4 & 13.3 & 13.2 \\
\hline Population (millions) & 10.0 & 10.1 & 10.2 & 10.4 & 10.5 & 10.6 & 10.8 & 10.9 & 11.0 \\
\hline Exchange rate: dinar $/ \$$ (average) & 1.30 & 1.33 & 1.28 & $\ldots$ & $\ldots$ & $\ldots$ & $\ldots$ & $\cdots$ & ... \\
\hline
\end{tabular}

Sources: Tunisian authorities; and IMF staff estimates and projections.

1/ Information Notice System.

2/ Excludes the social security accounts.

3/ Financial system (deposit money banks and development banks).

$4 /$ The rate for 2008 is from July 2.

5/ TUNINDEX. $(1000=$ 4/1/1998). 2008 data from July 3, 2008. 
Table 2. Balance of Payments, 2005-13

(In millions of U.S. dollars, unless otherwise indicated)

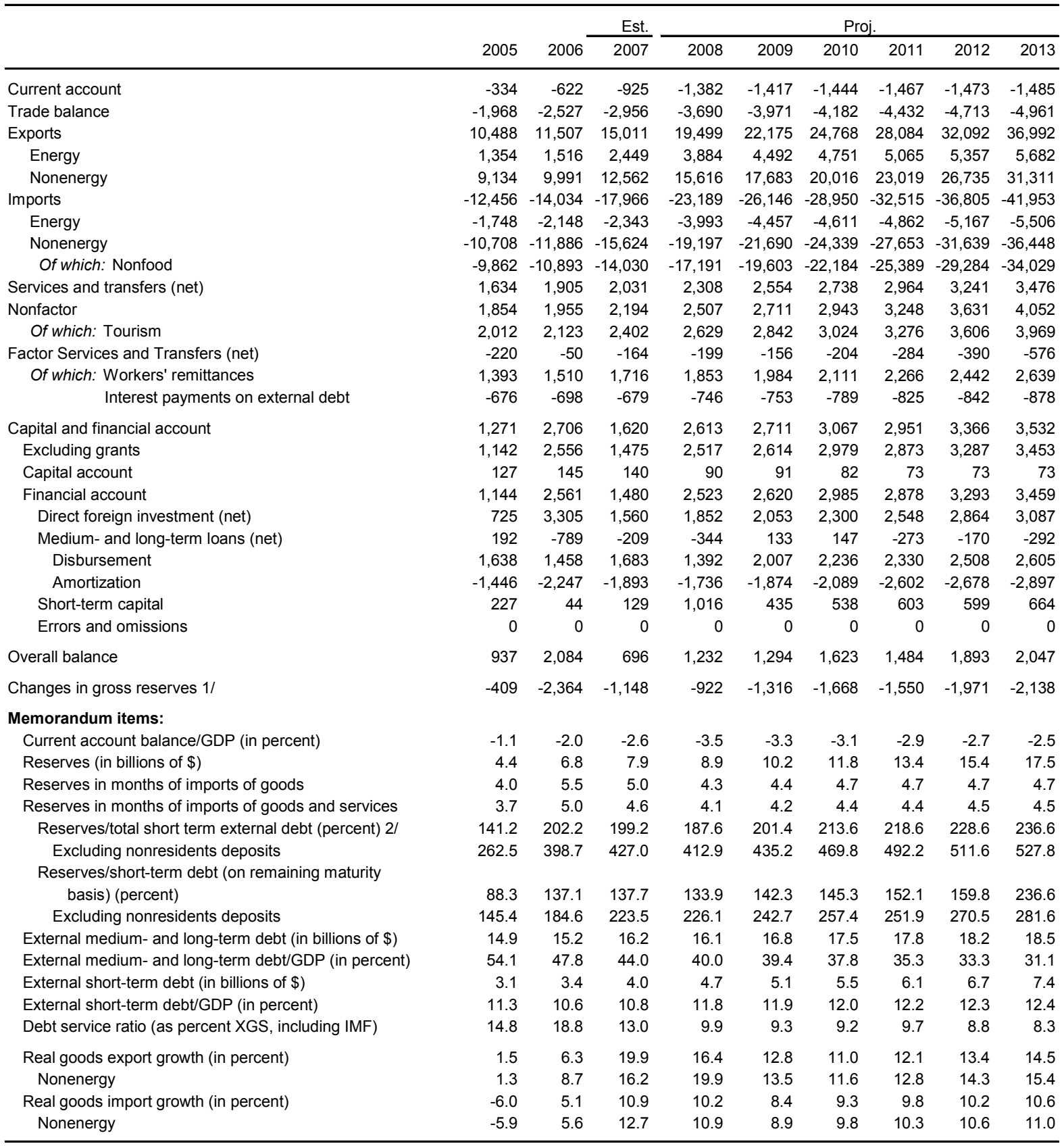

Sources: Tunisian authorities; and IMF staff estimates and projections.

$1 /$ Differs from the overall balance because of valuation effects.

2/ Short term defined as 1 year and less. 
Table 3. Central Government Financial Operations, 2005-13 1/

\begin{tabular}{|c|c|c|c|c|c|c|c|c|c|c|c|}
\hline & \multirow[b]{2}{*}{2005} & \multirow{2}{*}{$\frac{\text { Prel. }}{2006}$} & \multirow{2}{*}{$\frac{\mathrm{LdF}}{2007}$} & \multirow{2}{*}{$\frac{\text { Prel. }}{2007}$} & \multirow{2}{*}{$\frac{\mathrm{LdF}}{2008}$} & \multicolumn{6}{|c|}{ Projections } \\
\hline & & & & & & 2008 & 2009 & 2010 & 2011 & 2012 & 2013 \\
\hline & \multicolumn{10}{|c|}{ (In millions of dinars) } & \\
\hline Total revenue and grants and privatization & 9146 & 12838 & 10303 & 10949 & 11634 & 12334 & 13292 & 14498 & 15884 & 17148 & 18527 \\
\hline Total revenue & 8906 & 9789 & 10153 & 10862 & 11414 & 12114 & 13072 & 14278 & 15664 & 16928 & 18307 \\
\hline Tax revenue & 7904 & 8470 & 8862 & 9518 & 10028 & 10378 & 11224 & 12256 & 13449 & 14586 & 15806 \\
\hline Direct taxes & 2886 & 3107 & 3427 & 3708 & 4028 & 4328 & 4682 & 5122 & 5612 & 6039 & 6548 \\
\hline Trade taxes & 506 & 490 & 415 & 514 & 460 & 510 & 569 & 640 & 723 & 820 & 934 \\
\hline VAT & 2301 & 2466 & 2704 & 2660 & 2937 & 2937 & 3201 & 3513 & 3910 & 4301 & 4679 \\
\hline Domestic & 1189 & 1252 & 1390 & 1346 & 1467 & 1467 & 1592 & 1742 & 1908 & 2078 & 2253 \\
\hline Imports & 1112 & 1214 & 1314 & 1314 & 1470 & 1470 & 1608 & 1771 & 2001 & 2224 & 2427 \\
\hline Excise & 1212 & 1255 & 1285 & 1362 & 1423 & 1423 & 1494 & 1579 & 1667 & 1748 & 1819 \\
\hline Domestic & 741 & 759 & 815 & 824 & 849 & 849 & 918 & 1005 & 1101 & 1198 & 1299 \\
\hline Imports & 471 & 496 & 470 & 538 & 574 & 574 & 576 & 574 & 567 & 549 & 519 \\
\hline Other taxes & 999 & 1153 & 1031 & 1274 & 1180 & 1180 & 1279 & 1401 & 1538 & 1678 & 1826 \\
\hline Domestic & 928 & 1066 & 981 & 1176 & 1114 & 1114 & 1205 & 1318 & 1444 & 1572 & 1705 \\
\hline Imports & 72 & 87 & 51 & 98 & 66 & 66 & 74 & 83 & 94 & 106 & 121 \\
\hline Nontax revenue & 996 & 1314 & 1289 & 1339 & 1383 & 1733 & 1848 & 2022 & 2215 & 2342 & 2501 \\
\hline Capital income & 6 & 6 & 2 & 5 & 3 & 3 & 0 & 0 & 0 & 0 & 0 \\
\hline Total expenditure and net lending & 10119 & 10968 & 11512 & 12197 & 12882 & 13582 & 14633 & 15940 & 17392 & 18761 & 20204 \\
\hline Total expenditure & 10103 & 10856 & 11502 & 11843 & 12853 & 13553 & 14604 & 15911 & 17363 & 18732 & 20175 \\
\hline Current expenditure & 7693 & 8317 & 8804 & 9166 & 9856 & 10506 & 11201 & 12129 & 13156 & 14152 & 15210 \\
\hline Wages and salaries & 4560 & 4901 & 5378 & 5297 & 5744 & 5794 & 6268 & 6858 & 7513 & 8178 & 8868 \\
\hline Goods and services & 713 & 744 & 719 & 789 & 777 & 877 & 1109 & 1213 & 1393 & 1516 & 1644 \\
\hline Interest payments & 1062 & 1130 & 1120 & 1182 & 1240 & 1240 & 1268 & 1341 & 1415 & 1500 & 1616 \\
\hline Domestic & 473 & 499 & 520 & 582 & 615 & 615 & 648 & 679 & 719 & 801 & 914 \\
\hline External & 589 & 631 & 600 & 600 & 625 & 625 & 620 & 662 & 695 & 700 & 702 \\
\hline Transfers and subsidies & 1359 & 1542 & 1527 & 1898 & 1938 & 2438 & 2556 & 2716 & 2836 & 2957 & 3082 \\
\hline Food subsidies & 244 & 307 & 315 & 670 & 700 & 1000 & 1050 & 1125 & 1150 & 1200 & 1250 \\
\hline Petroleum subsidies & 414 & 500 & 450 & 450 & 400 & 600 & 600 & 600 & 600 & 575 & 550 \\
\hline Other & 701 & 736 & 762 & 778 & 838 & 838 & 906 & 991 & 1086 & 1182 & 1282 \\
\hline Other expenditure (nonallocated) & 0 & 0 & 60 & 0 & 157 & 157 & 0 & 0 & 0 & 0 & 0 \\
\hline Capital expenditure & 2409 & 2539 & 2698 & 2677 & 2997 & 3047 & 3403 & 3782 & 4207 & 4579 & 4965 \\
\hline Direct investment & 1259 & 1412 & 1448 & 1413 & 1545 & 1545 & 1949 & 2191 & 2401 & 2613 & 2834 \\
\hline Capital transfers and equity & 1150 & 1127 & 1120 & 1264 & 1294 & 1344 & 1453 & 1590 & 1806 & 1966 & 2132 \\
\hline Other expenditure (nonallocated) & 0 & 0 & 131 & 0 & 158 & 158 & 0 & 0 & 0 & 0 & 0 \\
\hline Net lending & 16 & 112 & 10 & 354 & 29 & 29 & 29 & 29 & 29 & 29 & 29 \\
\hline $\begin{array}{l}\text { Central government deficit (-) } \\
\text { (excluding grants and privati }\end{array}$ & & & & & & & & & & & \\
\hline $\begin{array}{l}\text { Gexclu } \\
\text { Grants }\end{array}$ & $\begin{array}{r}213 \\
70\end{array}$ & $\begin{array}{r}-11 / 9 \\
48\end{array}$ & $\begin{array}{r}-1359 \\
100\end{array}$ & $\begin{array}{r}-1336 \\
38\end{array}$ & $\begin{array}{r}-1468 \\
120\end{array}$ & $\begin{array}{l}1468 \\
120\end{array}$ & $\begin{array}{r}-1560 \\
120\end{array}$ & $\begin{array}{r}-1662 \\
120\end{array}$ & $-1 / 28$ & $\begin{array}{r}-1833 \\
120\end{array}$ & $\begin{array}{r}-189 / \\
120\end{array}$ \\
\hline Privatization proceeds $2 /$ & 170 & 3000 & 50 & 50 & 100 & 100 & 100 & 100 & 100 & 100 & 100 \\
\hline $\begin{array}{l}\text { Central government deficit (-) (including } \\
\text { grants and privatization) }\end{array}$ & -973 & 1870 & -1209 & -1248 & -1248 & -1248 & -1340 & -1442 & -1508 & -1613 & -1677 \\
\hline Financing & 973 & -1870 & 1209 & 1248 & 1248 & 1248 & 1340 & 1442 & 1508 & 1613 & 1677 \\
\hline Foreign & 284 & -1222 & -292 & -268 & -178 & -178 & 451 & 419 & -147 & -136 & -350 \\
\hline Domestic & 689 & -647 & 1501 & 1516 & 1426 & 1426 & 889 & 1023 & 1654 & 1749 & 2027 \\
\hline Memorandum items: & & & & & & & & & & & \\
\hline $\begin{array}{l}\text { Balance of the central government } \\
\text { (including grants, excluding private) }\end{array}$ & -1143 & -1131 & -1259 & -1298 & -1348 & -1348 & -1440 & -1542 & -1608 & -1713 & -1777 \\
\hline Central government primary balance & 89 & 2999 & -89 & -66 & -8 & -8 & -72 & -101 & -93 & -112 & -60 \\
\hline Central government primary balance & & & & & & & & & & & \\
\hline (excluding grants and privatization) & -151 & -49 & -239 & -154 & -228 & -228 & -292 & -321 & -313 & -332 & -280 \\
\hline General government debt 3/ & 21948 & 22222 & 24126 & 22839 & 24653 & 23143 & 24510 & 25836 & 27178 & 28972 & 30794 \\
\hline Of which: Domestic & 7923 & 8936 & 10844 & 9529 & 11446 & 9946 & 10427 & 11042 & 12287 & 14026 & 16043 \\
\hline External & 14025 & 13286 & 13282 & 13310 & 13208 & 13198 & 14083 & 14794 & 14891 & 14946 & 14751 \\
\hline Nominal GDP & 37664 & 41211 & 44245 & 44861 & 48564 & 49277 & 53303 & 58323 & 63891 & 69551 & 75412 \\
\hline Nominal nonagricultural GDP & 33574 & 36778 & 40166 & 40166 & 43589 & 44265 & 47955 & 52605 & 57813 & 63110 & 68598 \\
\hline Oil price (\$/barrel) & 53 & 64 & 70 & 71 & 86 & 117 & 125 & 124 & 124 & 124 & 124 \\
\hline Imports & 16161 & 18679 & 23021 & 23021 & 25880 & 29040 & 32415 & 36426 & 41160 & 46692 & 53194 \\
\hline
\end{tabular}


Table 3. Central Government Financial Operations, 2005-13 1/ (concluded)

\begin{tabular}{|c|c|c|c|c|c|c|c|c|c|c|c|}
\hline & \multirow[b]{2}{*}{2005} & \multirow{2}{*}{$\frac{\text { Est. }}{2006}$} & \multirow{2}{*}{$\frac{\mathrm{LdF}}{2007}$} & \multirow{2}{*}{$\frac{\text { Est. }}{2007}$} & \multirow{2}{*}{$\frac{\mathrm{LdF}}{2008}$} & \multicolumn{6}{|c|}{ Projections } \\
\hline & & & & & & 2008 & 2009 & 2010 & 2011 & 2012 & 2013 \\
\hline & \multicolumn{10}{|c|}{ (In percent of GDP) } & \\
\hline Total revenue and grants and privatization & 24.3 & 31.2 & 23.3 & 24.4 & 24.0 & 25.0 & 24.9 & 24.9 & 24.9 & 24.7 & 24.6 \\
\hline Total revenue & 23.6 & 23.8 & 22.9 & 24.2 & 23.5 & 24.6 & 24.5 & 24.5 & 24.5 & 24.3 & 24.3 \\
\hline Tax revenue & 21.0 & 20.6 & 20.0 & 21.2 & 20.6 & 21.1 & 21.1 & 21.0 & 21.1 & 21.0 & 21.0 \\
\hline Direct taxes & 7.7 & 7.5 & 7.7 & 8.3 & 8.3 & 8.8 & 8.8 & 8.8 & 8.8 & 8.7 & 8.7 \\
\hline Trade taxes & 1.3 & 1.2 & 0.9 & 1.1 & 0.9 & 1.0 & 1.1 & 1.1 & 1.1 & 1.2 & 1.2 \\
\hline Trade taxes (in percent of imports) & 3.1 & 2.6 & 1.8 & 2.2 & 1.8 & 1.8 & 1.8 & 1.8 & 1.8 & 1.8 & 1.8 \\
\hline VAT & 6.1 & 6.0 & 6.1 & 5.9 & 6.0 & 6.0 & 6.0 & 6.0 & 6.1 & 6.2 & 6.2 \\
\hline Domestic & 3.2 & 3.0 & 3.1 & 3.0 & 3.0 & 3.0 & 3.0 & 3.0 & 3.0 & 3.0 & 3.0 \\
\hline Imports & 3.0 & 2.9 & 3.0 & 2.9 & 3.0 & 3.0 & 3.0 & 3.0 & 3.1 & 3.2 & 3.2 \\
\hline Imports (in percent of imports) & 6.9 & 6.5 & 5.7 & 5.7 & 5.7 & 5.1 & 5.0 & 4.9 & 4.9 & 4.8 & 4.6 \\
\hline Excise & 3.2 & 3.0 & 2.9 & 3.0 & 2.9 & 2.9 & 2.8 & 2.7 & 2.6 & 2.5 & 2.4 \\
\hline Domestic & 2.0 & 1.8 & 1.8 & 1.8 & 1.7 & 1.7 & 1.7 & 1.7 & 1.7 & 1.7 & 1.7 \\
\hline Imports & 1.3 & 1.2 & 1.1 & 1.2 & 1.2 & 1.2 & 1.1 & 1.0 & 0.9 & 0.8 & 0.7 \\
\hline Imports (in percent of imports) & 2.9 & 2.7 & 2.0 & 2.3 & 2.2 & 2.0 & 1.8 & 1.6 & 1.4 & 1.2 & 1.0 \\
\hline Other taxes & 2.7 & 2.8 & 2.3 & 2.8 & 2.4 & 2.4 & 2.4 & 2.4 & 2.4 & 2.4 & 2.4 \\
\hline Domestic & 2.5 & 2.6 & 2.2 & 2.6 & 2.3 & 2.3 & 2.3 & 2.3 & 2.3 & 2.3 & 2.3 \\
\hline Imports & 0.2 & 0.2 & 0.1 & 0.2 & 0.1 & 0.1 & 0.1 & 0.1 & 0.1 & 0.2 & 0.2 \\
\hline Imports (in percent of imports) & 0.4 & 0.5 & 0.2 & 0.4 & 0.3 & 0.2 & 0.2 & 0.2 & 0.2 & 0.2 & 0.2 \\
\hline Nontax revenue & 2.6 & 3.2 & 2.9 & 3.0 & 2.8 & 3.5 & 3.5 & 3.5 & 3.5 & 3.4 & 3.3 \\
\hline Capital income & 0.0 & 0.0 & 0.0 & 0.0 & 0.0 & 0.0 & 0.0 & 0.0 & 0.0 & 0.0 & 0.0 \\
\hline Total expenditure and net lending & 26.9 & 26.6 & 26.0 & 27.2 & 26.5 & 27.6 & 27.5 & 27.3 & 27.2 & 27.0 & 26.8 \\
\hline Total expenditure & 26.8 & 26.3 & 26.0 & 26.4 & 26.5 & 27.5 & 27.4 & 27.3 & 27.2 & 26.9 & 26.8 \\
\hline Current expenditure & 20.4 & 20.2 & 19.9 & 20.4 & 20.3 & 21.3 & 21.0 & 20.8 & 20.6 & 20.3 & 20.2 \\
\hline Wages and salaries & 12.1 & 11.9 & 12.2 & 11.8 & 11.8 & 11.8 & 11.8 & 11.8 & 11.8 & 11.8 & 11.8 \\
\hline Goods and services & 1.9 & 1.8 & 1.6 & 1.8 & 1.6 & 1.8 & 2.1 & 2.1 & 2.2 & 2.2 & 2.2 \\
\hline Interest payments & 2.8 & 2.7 & 2.5 & 2.6 & 2.6 & 2.5 & 2.4 & 2.3 & 2.2 & 2.2 & 2.1 \\
\hline Domestic & 1.3 & 1.2 & 1.2 & 1.3 & 1.3 & 1.2 & 1.2 & 1.2 & 1.1 & 1.2 & 1.2 \\
\hline External & 1.6 & 1.5 & 1.4 & 1.3 & 1.3 & 1.3 & 1.2 & 1.1 & 1.1 & 1.0 & 0.9 \\
\hline Transfers and subsidies & 3.6 & 3.7 & 3.5 & 4.2 & 4.0 & 4.9 & 4.8 & 4.7 & 4.4 & 4.3 & 4.1 \\
\hline Food subsidies & 0.6 & 0.7 & 0.7 & 1.5 & 1.4 & 2.0 & 2.0 & 1.9 & 1.8 & 1.7 & 1.7 \\
\hline Petroleum subsidies & 1.1 & 1.2 & 1.0 & 1.0 & 0.8 & 1.2 & 1.1 & 1.0 & 0.9 & 0.8 & 0.7 \\
\hline Other & 1.9 & 1.8 & 1.7 & 1.7 & 1.7 & 1.7 & 1.7 & 1.7 & 1.7 & 1.7 & 1.7 \\
\hline Other expenditure (nonallocated) & 0.0 & 0.0 & 0.1 & 0.0 & 0.3 & 0.3 & 0.0 & 0.0 & 0.0 & 0.0 & 0.0 \\
\hline Capital expenditure & 6.4 & 6.2 & 6.1 & 6.0 & 6.2 & 6.2 & 6.4 & 6.5 & 6.6 & 6.6 & 6.6 \\
\hline Direct investment & 3.3 & 3.4 & 3.3 & 3.2 & 3.2 & 3.1 & 3.7 & 3.8 & 3.8 & 3.8 & 3.8 \\
\hline Capital transfers and equity & 3.1 & 2.7 & 2.5 & 2.8 & 2.7 & 2.7 & 2.7 & 2.7 & 2.8 & 2.8 & 2.8 \\
\hline Other expenditure (nonallocated) & 0.0 & 0.0 & 0.3 & 0.0 & 0.3 & 0.3 & 0.0 & 0.0 & 0.0 & 0.0 & 0.0 \\
\hline Net lending & 0.0 & 0.3 & 0.0 & 0.8 & 0.1 & 0.1 & 0.1 & 0.0 & 0.0 & 0.0 & 0.0 \\
\hline $\begin{array}{l}\text { Central government deficit (-), (excluding g } \\
\text { and privatization) }\end{array}$ & -3.2 & -2.9 & -3.1 & -3.0 & -3.0 & -3.0 & -2.9 & -2.8 & -2.7 & -2.6 & -2.5 \\
\hline Grants & 0.2 & 0.1 & 0.2 & 0.1 & 0.2 & 0.2 & 0.2 & 0.2 & 0.2 & 0.2 & 0.2 \\
\hline Privatization proceeds $2 /$ & 0.5 & 7.3 & 0.1 & 0.1 & 0.2 & 0.2 & 0.2 & 0.2 & 0.2 & 0.1 & 0.1 \\
\hline $\begin{array}{l}\text { Central government deficit (-), (including gr } \\
\text { and privatization) }\end{array}$ & -2.6 & 4.5 & -2.7 & -2.8 & -2.6 & -2.5 & -2.5 & -2.5 & -2.4 & -2.3 & -2.2 \\
\hline Financing & 2.6 & -4.5 & 2.7 & 2.8 & 2.6 & 2.5 & 2.5 & 2.5 & 2.4 & 2.3 & 2.2 \\
\hline Foreign & 0.8 & -3.0 & -0.7 & -0.6 & -0.4 & -0.4 & 0.8 & 0.7 & -0.2 & -0.2 & -0.5 \\
\hline Domestic & 1.8 & -1.6 & 3.4 & 3.4 & 2.9 & 2.9 & 1.7 & 1.8 & 2.6 & 2.5 & 2.7 \\
\hline Memorandum items: & & & & & & & & & & & \\
\hline $\begin{array}{l}\text { Balance of the central government (inclu } \\
\text { grants, excluding privatization) }\end{array}$ & 3.0 & -2.7 & -2.8 & & & & -2.7 & -2.6 & -2.5 & -2.5 & -2.4 \\
\hline Central government primary balance & 0.2 & 7.3 & -0.2 & -0.1 & 0.0 & $\begin{array}{r}-2.1 \\
0.0\end{array}$ & $\begin{array}{l}-2.1 \\
-0.1\end{array}$ & $\begin{array}{l}-2.0 \\
-0.2\end{array}$ & $\begin{array}{l}-2.5 \\
-0.1\end{array}$ & $\begin{array}{l}-2.5 \\
-0.2\end{array}$ & $\begin{array}{l}-2.4 \\
-0.1\end{array}$ \\
\hline Central government primary balance (ex & & & & & & & & & & & \\
\hline grants and privatization) & -0.4 & -0.1 & -0.54 & -0.3 & -0.5 & -0.5 & -0.5 & -0.5 & -0.5 & -0.5 & -0.4 \\
\hline General government debt $3 /$ & 58.3 & 53.9 & 54.5 & 50.9 & 50.8 & 47.0 & 46.0 & 44.3 & 42.5 & 41.7 & 40.8 \\
\hline Of which: Domestic & 21.0 & 21.7 & 24.5 & 21.2 & 23.6 & 20.2 & 19.6 & 18.9 & 19.2 & 20.2 & 21.3 \\
\hline External & 37.2 & 32.2 & 30.0 & 29.7 & 27.2 & 26.8 & 26.4 & 25.4 & 23.3 & 21.5 & 19.6 \\
\hline
\end{tabular}

Sources: Tunisian authorities; and IMF staff estimates.

$1 /$ Includes special funds, fonds de concours. Does not include the social security system (CSS)

2/ Privatization receipts from Tunisie Telecom (TT) were about TD 3000 millions in 2006.

3 / Gross debt: includes debt held by social security funds (CSS); excludes debt of public enterprises. 
Table 4. Monetary Survey (Financial System), 2004-08

\begin{tabular}{|c|c|c|c|c|c|}
\hline & 2004 & 2005 & 2006 & $\frac{\text { Est. }}{2007}$ & $\frac{\text { Projections }}{2008}$ \\
\hline & \multicolumn{5}{|c|}{ (In millions of dinars) } \\
\hline Foreign assets (net) & 3,126 & 4,112 & 6,876 & 7,807 & 9,057 \\
\hline Foreign assets & 5,802 & 7,341 & 10,230 & 11,715 & 12,818 \\
\hline $\mathrm{BCT}$ & 4,843 & 6,060 & 8,837 & 9,719 & 10,897 \\
\hline Foreign liabilities & $-2,675$ & $-3,229$ & $-3,354$ & $-3,908$ & $-3,762$ \\
\hline Net domestic assets & 18,340 & 19,708 & 19,670 & 22,046 & 23,931 \\
\hline Domestic credit & 26,366 & 28,149 & 30,745 & 33,777 & 36,643 \\
\hline Credit to the government (net) & 3,283 & 3,611 & 4,589 & 5,096 & 5,524 \\
\hline Central bank net credit & -597 & -636 & -243 & -256 & -256 \\
\hline Commercial banks & 2,180 & 2,275 & 2,609 & 2,817 & 3,245 \\
\hline Credit to the economy & 23,083 & 24,538 & 26,157 & 28,681 & 31,118 \\
\hline Other items (net) & $-8,026$ & $-8,441$ & $-11,075$ & $-11,731$ & $-12,712$ \\
\hline Money plus quasi-money (M2) & 19,846 & 22,129 & 24,834 & 28,197 & 30,904 \\
\hline Money (M1) & 7,686 & 8,742 & 9,871 & 11,083 & 12,147 \\
\hline Currency & 2,968 & 3,478 & 3,873 & 4,099 & 4,492 \\
\hline Demand deposits & 4,718 & 5,263 & 5,998 & 6,984 & 7,655 \\
\hline Quasi-money & 12,161 & 13,388 & 14,963 & 17,115 & 18,758 \\
\hline Long-term deposits (M3-M2) & 1,620 & 1,691 & 1,712 & 1,656 & 2,083 \\
\hline \multirow[t]{2}{*}{ Broad money (M3 ) 1/ } & 21,467 & 23,821 & 26,546 & 29,853 & 32,988 \\
\hline & \multicolumn{5}{|c|}{ (Annual rate of change in percent) } \\
\hline Foreign assets (net) & 37.2 & 31.5 & 67.2 & 13.5 & 16.0 \\
\hline Domestic credit & 6.9 & 6.8 & 9.2 & 9.9 & 8.5 \\
\hline Credit to government (net) & 19.0 & 10.0 & 27.1 & 11.1 & 8.4 \\
\hline Credit to the economy & 5.3 & 6.3 & 6.6 & 9.6 & 8.5 \\
\hline Money and quasi-money (M2) & 11.1 & 11.5 & 12.2 & 13.5 & 9.6 \\
\hline \multirow[t]{2}{*}{ Broad money (M3 ) } & 10.3 & 11.0 & 11.4 & 12.5 & 10.5 \\
\hline & \multicolumn{5}{|c|}{ (Changes in percent of initial stock of M3) } \\
\hline Foreign assets (net) & 4.4 & 4.6 & 11.6 & 3.5 & 4.2 \\
\hline Domestic credit & 8.7 & 8.3 & 10.9 & 11.4 & 9.6 \\
\hline Credit to the government (net) & 2.7 & 1.5 & 4.1 & 1.9 & 1.4 \\
\hline Credit to the economy & 6.0 & 6.8 & 6.8 & 9.5 & 8.2 \\
\hline Other items (net) & -2.7 & -1.9 & -11.1 & -2.5 & -3.3 \\
\hline \multicolumn{6}{|l|}{ Memorandum items: } \\
\hline Velocity (GDP/M3) & 1.64 & 1.58 & 1.55 & 1.50 & 1.50 \\
\hline Multiplier (M3/M0) & 5.65 & 5.14 & 4.87 & 4.75 & 4.39 \\
\hline GDP & 35,192 & 37,664 & 41,211 & 44,861 & 49,277 \\
\hline Nominal GDP growth & 9.4 & 7.0 & 9.4 & 8.9 & 9.8 \\
\hline
\end{tabular}

Sources: Tunisian authorities; and IMF staff estimates and projections.

1/ M2 plus long-term deposits. 
Table 5. Medium-Term Growth Scenario, 2005-13

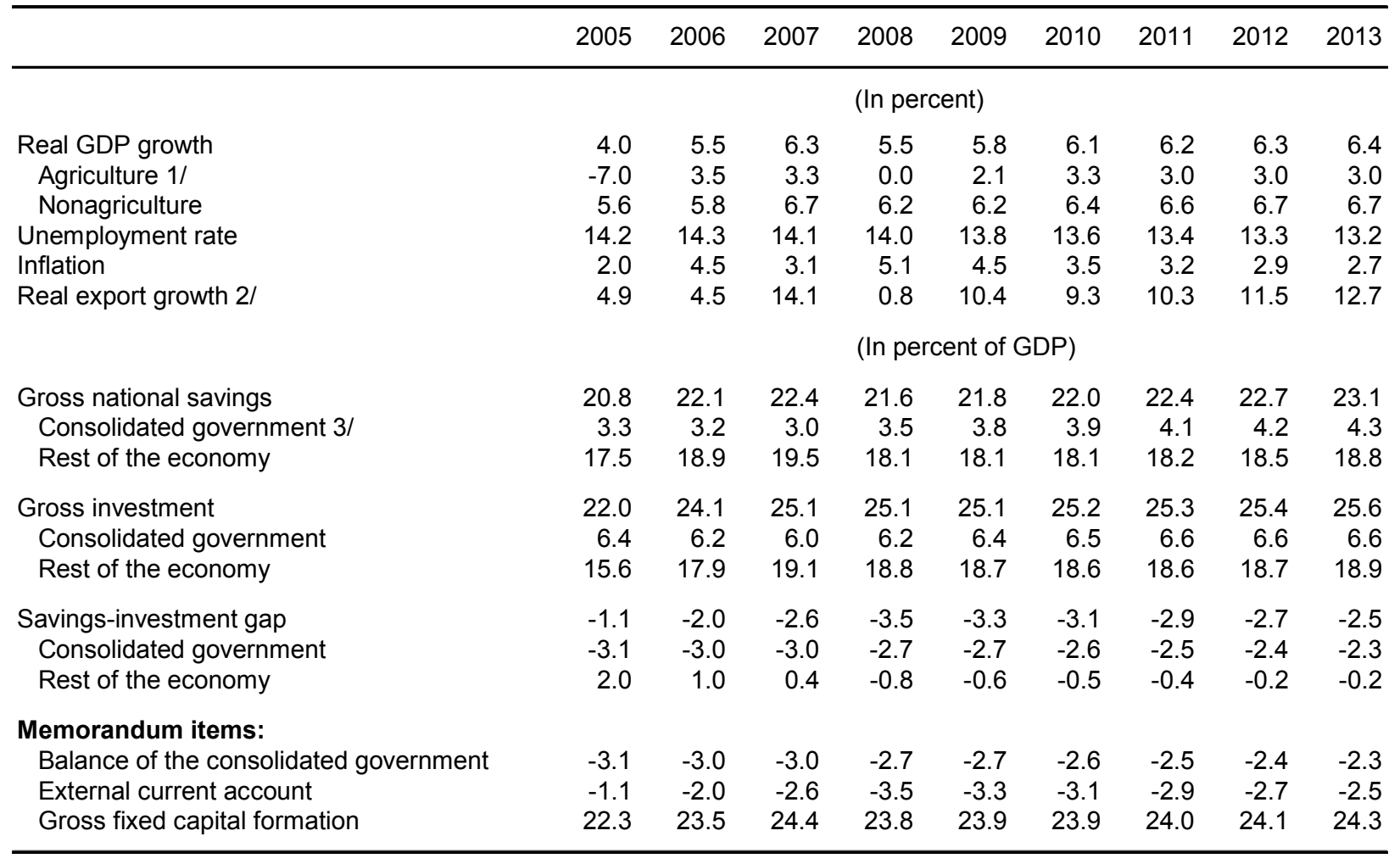

Sources: Tunisian authorities; and IMF staff estimates.

1/ Based on average growth of agricultural output from 2001 onward.

2/ Goods and nonfactor services.

$3 /$ Includes social security, excludes privatization receipts. 
Table 6. External Debt Sustainability Framework, 2003-13

(In percent of GDP, unless otherwise indicated)

\begin{tabular}{|c|c|c|c|c|c|c|c|c|c|c|c|c|}
\hline & \multicolumn{5}{|c|}{ Actual } & \multicolumn{7}{|c|}{ Projections } \\
\hline & 2003 & 2004 & 2005 & 2006 & 2007 & 2008 & 2009 & 2010 & 2011 & 2012 & 2013 & $\begin{array}{c}\text { Debt-stabilizing } \\
\text { noninterest }\end{array}$ \\
\hline Baseline: External debt & 66.8 & 66.5 & 65.4 & 58.3 & 54.9 & 51.8 & 51.2 & 49.9 & 47.5 & 45.6 & 43.6 & -7.3 \\
\hline Change in external debt & -0.7 & -0.3 & -1.1 & -7.1 & -3.5 & -3.1 & -0.5 & -1.4 & -2.4 & -1.9 & -2.0 & \\
\hline Identified external debt-creating flows $(4+8+9)$ & -10.0 & -6.5 & 2.6 & -17.2 & -9.7 & -4.0 & -4.4 & -4.8 & -5.0 & -5.4 & -5.4 & \\
\hline Current account deficit, excluding interest payments & 0.6 & -0.3 & -1.2 & -0.2 & 0.7 & 1.6 & 1.6 & 1.4 & 1.3 & 1.1 & 1.0 & \\
\hline Deficit in balance of goods and services & 3.4 & 2.5 & 0.4 & 1.8 & 2.1 & 2.9 & 3.0 & 2.7 & 2.4 & 2.0 & 1.5 & \\
\hline Exports & 40.7 & 44.9 & 52.0 & 49.4 & 53.8 & 62.2 & 66.2 & 67.7 & 69.8 & 72.9 & 76.8 & \\
\hline Imports & 44.1 & 47.4 & 52.4 & 51.2 & 55.9 & 65.1 & 69.1 & 70.4 & 72.2 & 74.9 & 78.3 & \\
\hline Net nondebt creating capital inflows (negative) & -2.1 & -2.2 & -2.7 & -10.6 & -4.3 & -4.7 & -4.9 & -5.0 & -5.1 & -5.3 & -5.2 & \\
\hline Automatic debt dynamics $1 /$ & -8.5 & -4.0 & 6.6 & -6.3 & -6.0 & -0.9 & -1.1 & -1.2 & -1.2 & -1.2 & -1.2 & \\
\hline Contribution from nominal interest rate & 2.2 & 2.2 & 2.4 & 2.2 & 1.8 & 1.9 & 1.8 & 1.7 & 1.6 & 1.5 & 1.5 & \\
\hline Contribution from real GDP growth & -3.2 & -3.7 & -2.8 & -3.1 & -3.2 & -2.8 & -2.8 & -2.9 & -2.9 & -2.8 & -2.7 & \\
\hline Contribution from price and exchange rate changes $2 /$ & -7.5 & -2.5 & 6.9 & -5.4 & -4.7 & $\cdots$ & $\ldots$ & $\ldots$ & $\ldots$ & $\ldots$ & $\ldots$ & \\
\hline Residual, including change in gross foreign assets (2-3) $3 /$ & 9.3 & 6.2 & -3.8 & 10.1 & 6.2 & 0.9 & 3.9 & 3.4 & 2.7 & 3.4 & 3.4 & \\
\hline External debt-to-exports ratio (in percent) & 164.1 & 148.3 & 125.8 & 118.1 & 102.0 & 83.2 & 77.4 & 73.7 & 68.0 & 62.5 & 56.7 & \\
\hline $\begin{array}{l}\text { Gross external financing need (in billions of dollars) } 4 \text { I } \\
\text { In percent of GDP }\end{array}$ & $\begin{array}{r}4.7 \\
17.8\end{array}$ & $\begin{array}{r}5.3 \\
18.2\end{array}$ & $\begin{array}{r}5.1 \\
18.5\end{array}$ & $\begin{array}{r}6.0 \\
18.9\end{array}$ & $\begin{array}{r}6.2 \\
16.8\end{array}$ & $\begin{array}{r}7.1 \\
17.7\end{array}$ & $\begin{array}{r}8.0 \\
18.8\end{array}$ & $\begin{array}{r}8.6 \\
18.6\end{array}$ & $\begin{array}{r}9.6 \\
19.1\end{array}$ & $\begin{array}{l}10.3 \\
18.8\end{array}$ & $\begin{array}{l}11.1 \\
18.7\end{array}$ & \\
\hline Scenario with key variables at their historical averages $5 /$ & & & & & & 51.8 & 50.8 & 50.4 & 49.6 & 49.3 & 49.0 & -5.3 \\
\hline \multicolumn{13}{|l|}{ Key Macroeconomic Assumptions Underlying Baseline } \\
\hline Real GDP growth (in percent) & 5.6 & 6.0 & 4.0 & 5.5 & 6.3 & 5.5 & 5.8 & 6.1 & 6.2 & 6.3 & 6.4 & \\
\hline GDP deflator in dollars (change in percent) & 12.5 & 3.9 & -9.4 & 9.0 & 8.8 & 3.6 & 0.1 & 2.2 & 2.7 & 2.3 & 2.1 & \\
\hline Nominal external interest rate (in percent) & 3.8 & 3.6 & 3.5 & 3.9 & 3.7 & 3.7 & 3.6 & 3.6 & 3.6 & 3.5 & 3.5 & \\
\hline Growth of exports ( dollar terms, in percent) & 14.7 & 21.5 & 9.1 & 9.2 & 26.0 & 26.4 & 12.7 & 10.9 & 12.6 & 13.6 & 14.4 & \\
\hline Growth of imports ( dollar terms, in percent) & 14.4 & 18.4 & 4.1 & 12.3 & 26.2 & 27.5 & 12.4 & 10.4 & 12.0 & 12.8 & 13.6 & \\
\hline Current account balance, excluding interest payments & -0.6 & 0.3 & 1.2 & 0.2 & -0.7 & -1.6 & -1.6 & -1.4 & -1.3 & -1.1 & -1.0 & \\
\hline Net nondebt creating capital inflows & 2.1 & 2.2 & 2.7 & 10.6 & 4.3 & 4.7 & 4.9 & 5.0 & 5.1 & 5.3 & 5.2 & \\
\hline
\end{tabular}

1/ Derived as $[r-g-r(1+g)+e a(1+r)] /(1+g+r+g r)$ times previous period debt stock, with $r=$ nominal effective interest rate on external debt; $r=$ change in domestic GDP deflator in dollar terms, $g=$ real GDP growth rate, rate, $\mathrm{e}=$ nominal appreciation (increase in dollar value of domestic currency), and $\mathrm{a}=$ share of domestic-currency denominated debt in total external debt.

$2 /$ The contribution from price and exchange rate changes is defined as $[-r(1+g)+e a(1+r)] /(1+g+r+g r)$ times previous period debt stock. $r$ increases with an appreciating domestic currency $(\mathrm{e}>0)$ and rising inflation (based on GDP deflator).

3/ For projection, line includes the impact of price and exchange rate changes.

4/ Defined as current account deficit, plus amortization on medium- and long-term debt, plus short-term debt at end of previous period.

5/ The key variables include real GDP growth; nominal interest rate; dollar deflator growth; and both noninterest current account and nondebt inflows in percent of GDP

6/ Long run, constant balance that stabilizes the debt ratio assuming that key variables (real GDP growth, nominal interest rate, dollar deflator growth, and nondebt inflows in percent of

GDP) remain at their levels of the last projection year. 
Figure 1. External Debt Sustainability: Bound Tests 1/ (External debt in percent of GDP)
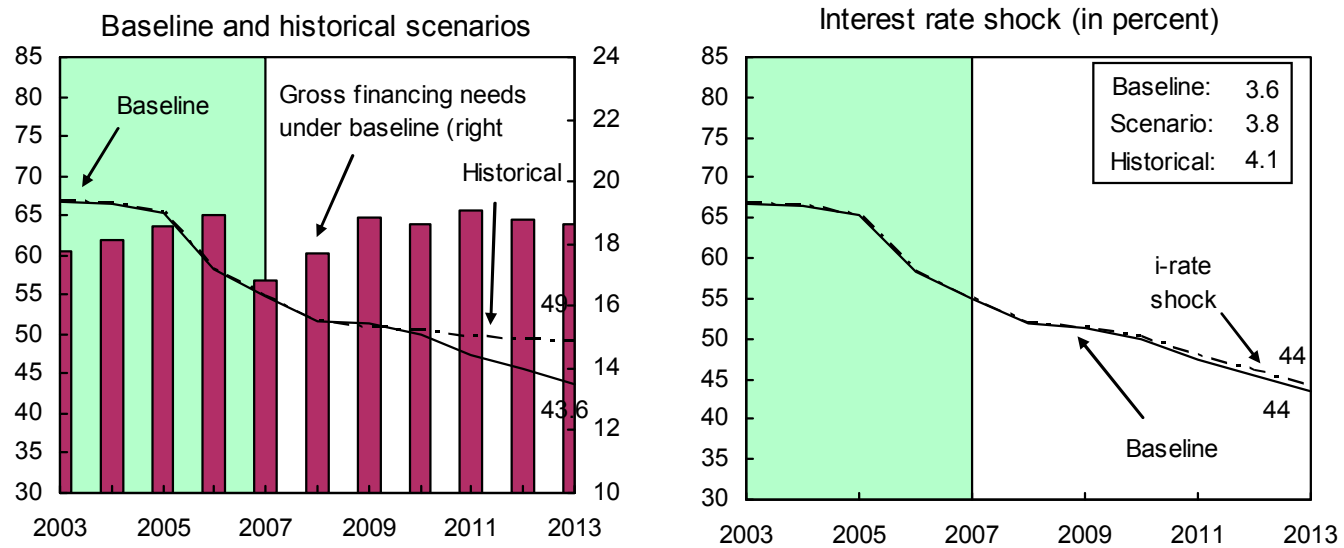

Growth shock (in percent per year)

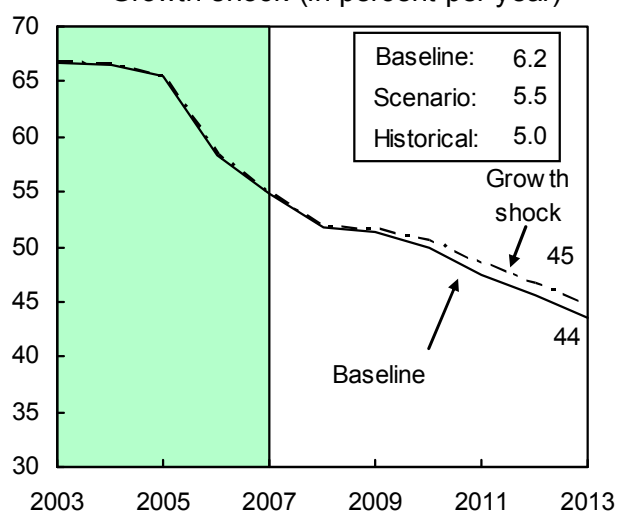

Noninterest current account shock

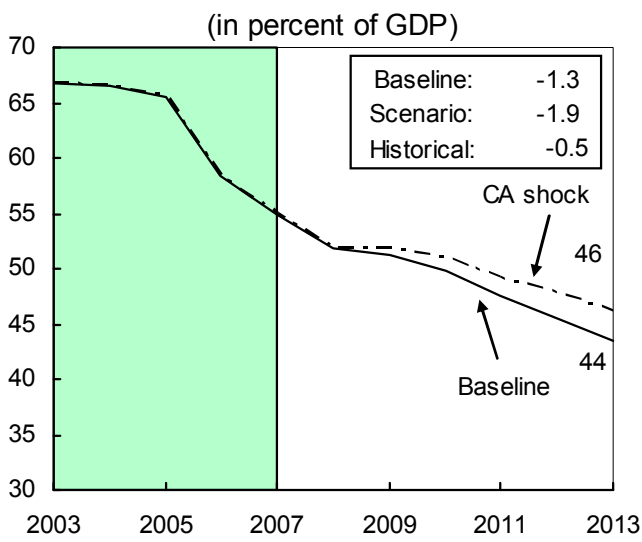

Combined shock $2 /$
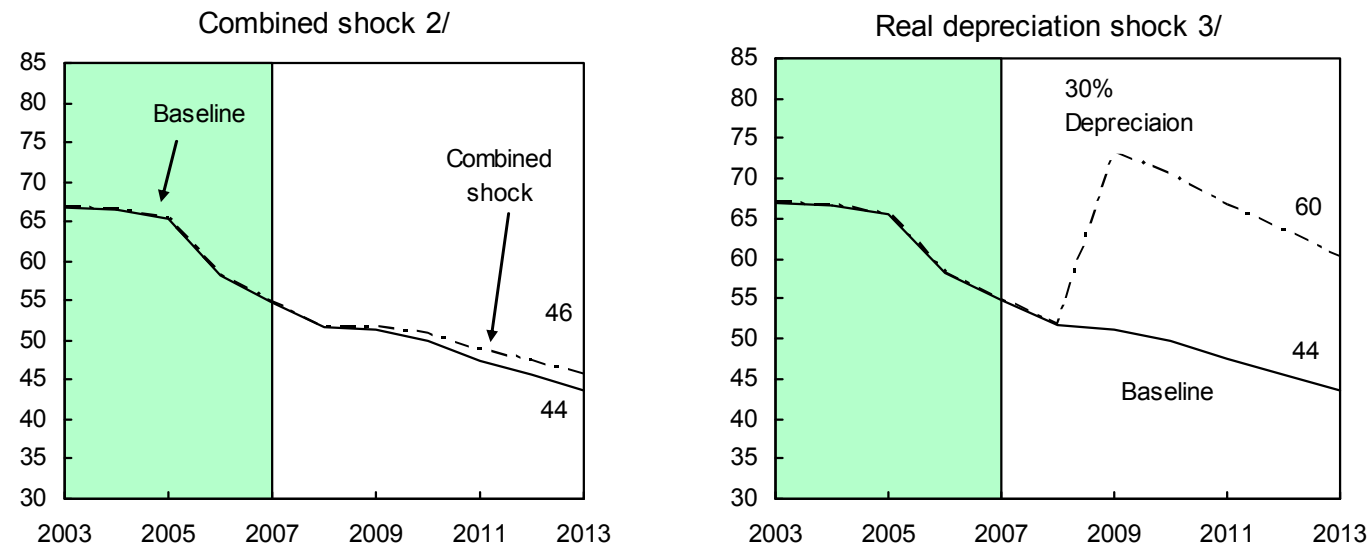

Sources: International Monetary Fund, Tunisian authorities, and IMF staff estimates.

1/ Shaded areas represent actual data. Individual shocks are permanent one-half standard deviation shocks. Figures in the boxes represent average projections for the respective variables in the baseline and scenario being presented. Ten-year historical average for the variable is also shown.

2/ Permanent $1 / 4$ standard deviation shocks applied to real interest rate, growth rate, and current account balance.

3/ One-time real depreciation of 30 percent occurs in 2009. 
Table 7. Public Sector Debt Sustainability Framework, 2003-13

(In percent of GDP, unless otherwise indicated)

\begin{tabular}{|c|c|c|c|c|c|c|c|c|c|c|c|c|}
\hline & \multicolumn{5}{|c|}{ Actual } & \multicolumn{6}{|c|}{ Projections } & \multirow{2}{*}{$\begin{array}{c}\text { Debt-stabilizing } \\
\text { primary } \\
\text { balance } 9 /\end{array}$} \\
\hline & 2003 & 2004 & 2005 & 2006 & 2007 & 2008 & 2009 & 2010 & 2011 & 2012 & 2013 & \\
\hline $\begin{array}{l}\text { Baseline: Public sector debt } 1 / \\
\text { Of which: foreign-currency denominated }\end{array}$ & $\begin{array}{l}60.5 \\
38.9\end{array}$ & $\begin{array}{l}59.4 \\
37.5\end{array}$ & $\begin{array}{l}58.3 \\
37.2\end{array}$ & $\begin{array}{l}53.9 \\
32.2\end{array}$ & $\begin{array}{l}50.9 \\
29.7\end{array}$ & $\begin{array}{l}47.0 \\
26.8\end{array}$ & $\begin{array}{l}46.0 \\
26.4\end{array}$ & $\begin{array}{l}44.3 \\
25.4\end{array}$ & 42.5 & $\begin{array}{l}41.7 \\
21.5\end{array}$ & $\begin{array}{l}40.8 \\
19.6\end{array}$ & 1.4 \\
\hline Change in public sector debt & -1.0 & -1.1 & -1.2 & -4.4 & -3.0 & -3.9 & -1.0 & -1.7 & -1.8 & -0.9 & -0.8 & \\
\hline Identified debt-creating flows $(4+7+12)$ & -4.8 & -3.3 & 3.8 & -11.0 & -3.3 & -2.0 & -1.0 & -1.5 & 1.6 & 1.7 & 1.6 & \\
\hline Primary deficit & 0.3 & -0.3 & 0.3 & 0.3 & 0.4 & 0.2 & 0.3 & 0.3 & 0.3 & 0.3 & 0.2 & \\
\hline Revenue and grants & 29.8 & 29.8 & 29.4 & 29.7 & 30.4 & 31.1 & 31.0 & 31.0 & 31.0 & 30.8 & 30.7 & \\
\hline Primary (noninterest) expenditure & 30.1 & 29.5 & 29.7 & 29.9 & 30.8 & 31.3 & 31.3 & 31.3 & 31.3 & 31.1 & 30.9 & \\
\hline Automatic debt dynamics $2 /$ & -5.1 & -2.7 & 3.9 & -4.0 & -3.6 & -2.0 & -1.2 & -1.7 & -1.6 & -1.3 & -1.1 & \\
\hline Contribution from interest rate/growth differential $3 /$ & -1.5 & -2.4 & -1.1 & -2.3 & -1.8 & -2.0 & -1.2 & -1.7 & -1.6 & -1.3 & -1.1 & \\
\hline Of which: Contribution from real interest rate & 1.7 & 1.0 & 1.1 & 0.7 & 1.4 & 0.5 & 1.3 & 0.9 & 0.9 & 1.2 & 1.3 & \\
\hline Contribution from real GDP growth & -3.2 & -3.3 & -2.2 & -2.9 & -3.1 & -2.5 & -2.5 & -2.6 & -2.5 & -2.5 & -2.4 & \\
\hline Contribution from exchange rate depreciation $4 /$ & -3.6 & -0.3 & 5.0 & -1.7 & -1.8 & $\ldots$ & $\ldots$ & $\ldots$ & $\ldots$ & & & \\
\hline Other identified debt-creating flows & 0.0 & -0.4 & -0.5 & -7.3 & -0.1 & -0.2 & -0.2 & -0.2 & 3.0 & 2.7 & 2.5 & \\
\hline Privatization receipts (negative) & 0.0 & -0.4 & -0.5 & -7.3 & -0.1 & -0.2 & -0.2 & -0.2 & -0.2 & -0.1 & -0.1 & \\
\hline Recognition of implicit or contingent liabilities & 0.0 & 0.0 & 0.0 & 0.0 & 0.0 & 0.0 & 0.0 & 0.0 & 1.6 & 1.4 & 1.3 & \\
\hline Other (specify, e.g., bank recapitalization) & 0.0 & 0.0 & 0.0 & 0.0 & 0.0 & 0.0 & 0.0 & 0.0 & 1.6 & 1.4 & 1.3 & \\
\hline Residual, including asset changes (2-3) 5/ & 3.8 & 2.3 & -4.9 & 6.7 & 0.3 & -1.9 & 0.1 & -0.2 & -3.4 & -2.6 & -2.4 & \\
\hline Public sector debt-to-revenue ratio $1 /$ & 203.4 & 199.2 & 198.0 & 181.6 & 167.5 & 150.9 & 148.1 & 143.0 & 137.2 & 135.2 & 132.9 & \\
\hline $\begin{array}{l}\text { Gross financing need } 6 / \\
\text { In billions of dollars }\end{array}$ & $\begin{array}{l}5.8 \\
1.5\end{array}$ & $\begin{array}{l}6.0 \\
1.7\end{array}$ & $\begin{array}{l}6.1 \\
1.8\end{array}$ & $\begin{array}{l}7.2 \\
2.2\end{array}$ & $\begin{array}{l}6.2 \\
2.2\end{array}$ & $\begin{array}{l}4.9 \\
1.9\end{array}$ & $\begin{array}{l}4.8 \\
2.0\end{array}$ & $\begin{array}{l}4.6 \\
2.1\end{array}$ & $\begin{array}{l}5.3 \\
2.7\end{array}$ & $\begin{array}{l}5.1 \\
2.8\end{array}$ & $\begin{array}{l}4.8 \\
2.9\end{array}$ & \\
\hline $\begin{array}{l}\text { Scenario with key variables at their historical averages } 71 \\
\text { Scenario with no policy change (constant primary balance) in 2008-13 }\end{array}$ & & & & & & $\begin{array}{l}47.0 \\
47.0\end{array}$ & $\begin{array}{l}45.6 \\
44.3\end{array}$ & $\begin{array}{l}44.0 \\
42.7\end{array}$ & $\begin{array}{l}42.3 \\
41.0\end{array}$ & $\begin{array}{l}41.3 \\
40.1\end{array}$ & $\begin{array}{l}40.3 \\
39.3\end{array}$ & $\begin{array}{l}1.6 \\
1.5\end{array}$ \\
\hline \multicolumn{13}{|l|}{ Key Macroeconomic and Fiscal Assumptions Underlying Baseline } \\
\hline Real GDP growth (in percent) & 5.6 & 6.0 & 4.0 & 5.5 & 6.3 & 5.5 & 5.8 & 6.1 & 6.2 & 6.3 & 6.4 & \\
\hline Average nominal interest rate on public debt (in percent) $8 /$ & 4.9 & 5.1 & 5.1 & 5.1 & 5.3 & 5.4 & 5.5 & 5.5 & 5.5 & 5.5 & 5.6 & \\
\hline Average real interest rate (nominal rate minus change in GDP & & & & & & & & & & & & \\
\hline deflator, in percent) & 3.1 & 1.9 & 2.1 & 1.5 & 2.9 & 1.3 & 3.2 & 2.3 & 2.4 & 3.2 & 3.6 & \\
\hline $\begin{array}{l}\text { Nominal appreciation (increase in dollar value of local currency, } \\
\text { in percent) }\end{array}$ & 10.4 & 0.7 & -12.0 & 5.1 & 6.3 & & & $\ldots$ & $\ldots$ & & & \\
\hline Inflation rate (GDP deflator, in percent) & 1.9 & 3.2 & 2.9 & 3.7 & 2.4 & 4.1 & 2.3 & 3.1 & 3.1 & 2.4 & 1.9 & \\
\hline Growth of real primary spending (deflated by GDP deflator, in percent) & 5.5 & 4.0 & 4.7 & 6.3 & 9.3 & 7.3 & 5.9 & 5.9 & 6.2 & 5.7 & 5.8 & \\
\hline Primary deficit & 0.3 & -0.3 & 0.3 & 0.3 & 0.4 & 0.2 & 0.3 & 0.3 & 0.3 & 0.3 & 0.2 & \\
\hline
\end{tabular}

1/ General government gross debt, including debt held by social security funds.

2/ Derived as $[(r-\pi(1+g)-g+\alpha \varepsilon(1+r)] /(1+g+\pi+g \pi))$ times previous period debt ratio, with $r=$ interest rate; $\pi=$ growth rate of GDP deflator; $g=$ real GDP growth rate; $\alpha=$ share of foreign-currency denominated debt; and $\mathrm{e}=$ nominal exchange rate depreciation (measured by increase in local currency value of dollar).

$3 /$ The real interest rate contribution is derived from the denominator in footnote $2 /$ as $r-\pi(1+g)$ and the real growth contribution as $-g$.

$4 /$ The exchange rate contribution is derived from the numerator in footnote $2 /$ as $\alpha \varepsilon(1+r)$.

The includes exchange rate changes.

-and long-term public sector debt, plus short-term debt at end of previous period.

(1)

/ Assumes that key variables (real GDP growth, real interest rate, and other identified debt-creating flows) remain at the level of the last projection year. 
Figure 2. Public Debt Sustainability: Bound Tests 1/ (Public debt in percent of GDP)

Baseline and historical scenarios

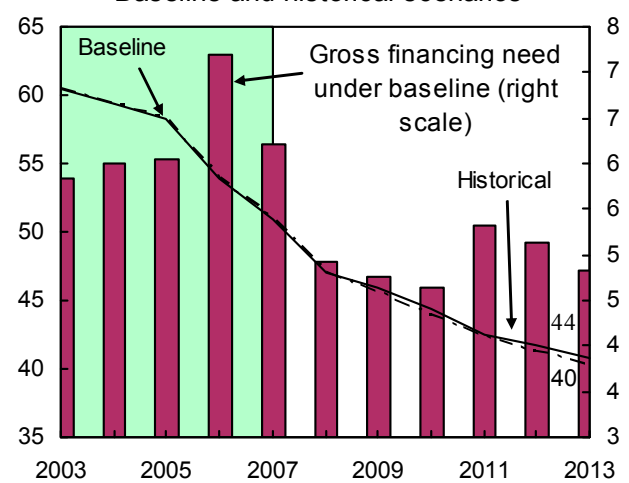

Growth shock (in percent per year)

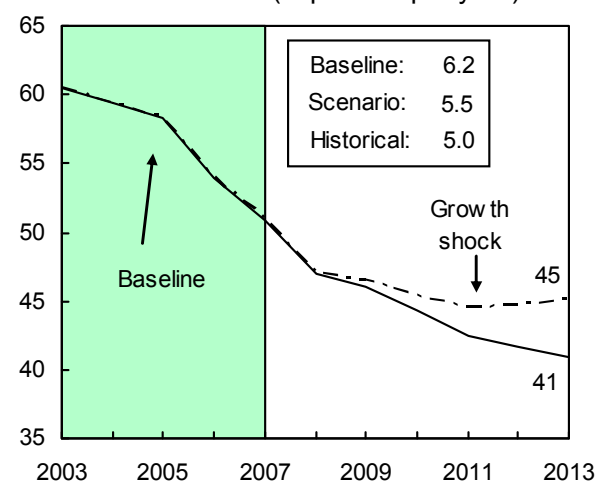

Combined shock 2/

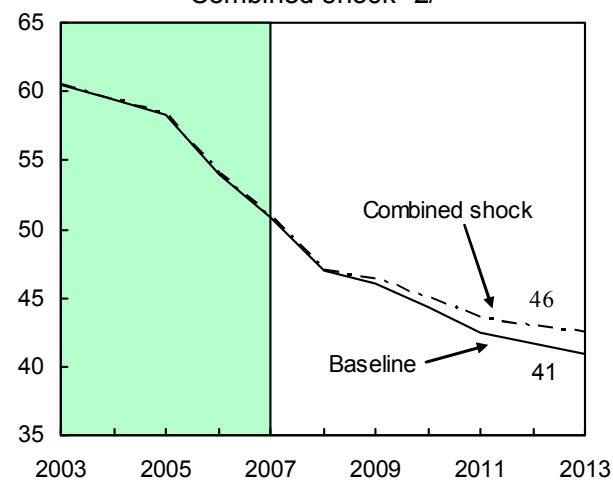

Interest rate shock (in percent)

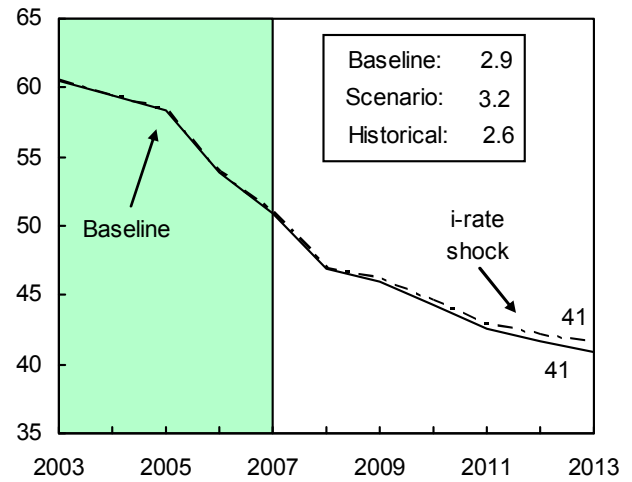

Primary balance shock (in percent of GDP) and no policy change scenario (constant primary balance)

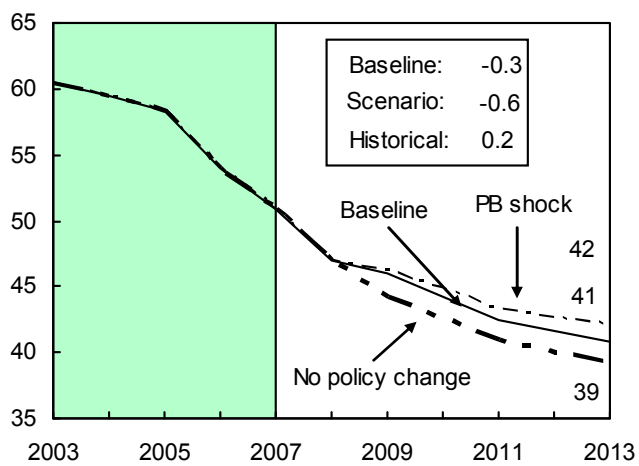

Real depreciation and contingent liabilities shocks $3 /$

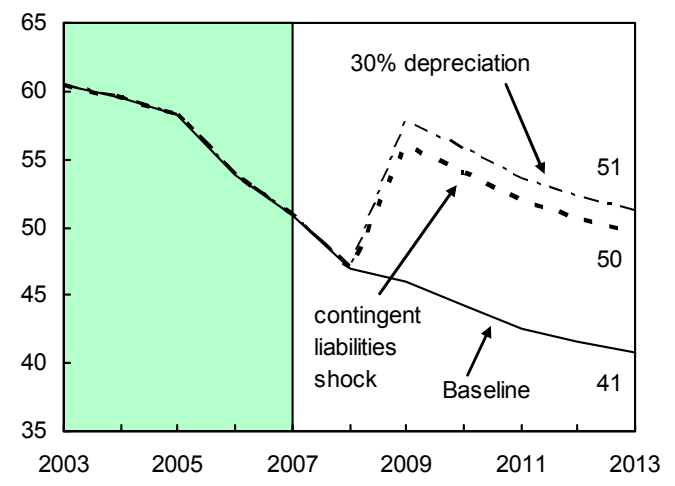

Sources: International Monetary Fund; country desk data; and IMF staff estimates.

1/ Shaded areas represent actual data. Individual shocks are permanent one-half standard deviation shocks. Figures in the boxes represent average projections for the respective variables in the baseline and scenario being presented. Ten-year historical average for the variable is also show $\mathrm{n}$.

2/ Permanent $1 / 4$ standard deviation shocks applied to real interest rate, grow th rate, and primary balance. $3 /$ One-time real depreciation of 30 percent and 10 percent of GDP shock to contingent liabilities occur in 2009 , $w$ ith real depreciation defined as nominal depreciation (measured by percentage fall in dollar value of local currency) minus domestic inflation (based on GDP deflator). 
INTERNATIONAL MONETARY FUND

TUNISIA

2008 Article IV Consultation

Informational Annex

Prepared by the Staff Representatives for the 2008 Consultation with Tunisia

July 22, 2008

Contents

Page

\section{Annexes}

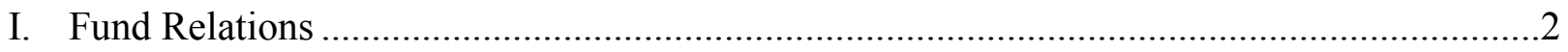

II. Financial Relations with the World Bank ....................................................................5

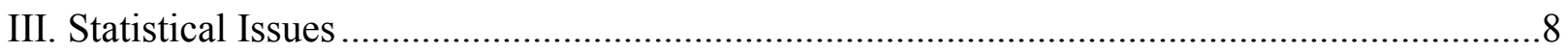




\section{AnNex I. Fund RELATIONS}

As of May 31, 2008

I. Membership Status: Joined: 04/14/1958; Article VIII

II. General Resources Account:

Quota

Fund Holdings of Currency

Reserve position in Fund

III. SDR Department:

Net cumulative allocation

Holdings $\underline{\text { SDR Million }}$

286.50

266.27

20.25

$\underline{\text { SDR Million }}$

34.24

7.04
$\%$ Quota

100.0

92.94

7.07

\%Allocation

100.0

10.81

IV. Outstanding Purchases and Loans:

None

V. Financial Arrangements:

\begin{tabular}{lcccc}
\multicolumn{1}{c}{ Type } & $\begin{array}{c}\text { Approval } \\
\text { Date }\end{array}$ & $\begin{array}{c}\text { Expiration } \\
\text { Date }\end{array}$ & $\begin{array}{c}\text { Amount Approved } \\
\text { (SDR Million) }\end{array}$ & $\begin{array}{c}\text { Amount Drawn } \\
\text { (SDR Million) }\end{array}$ \\
\hline EFF & $07 / 25 / 1988$ & $07 / 24 / 1992$ & 207.30 & 207.30 \\
Stand-by & $11 / 04 / 1986$ & $05 / 31 / 1988$ & 103.65 & 91.00
\end{tabular}

VI. Projected Obligations to Fund: (SDR Million; based on existing use of resources and present holdings of SDRs):

Forthcoming

\begin{tabular}{lccccc}
\hline & 2008 & 2009 & 2010 & 2011 & 2012 \\
\hline Principal & & & & & \\
Charges/Interest & 0.45 & 0.91 & 0.91 & 0.91 & 0.91 \\
Total & 0.45 & 0.91 & 0.91 & 0.91 & 0.91 \\
\hline
\end{tabular}




\section{Exchange Rate Arrangement and Exchange System}

Tunisia accepted the obligations of Article VIII Sections 2(a), 3, and 4 effective January 6, 1993, and maintains an exchange system that is free of restrictions on executing payments and transfers on current international transactions, except that Tunisia maintains (a) a multiple currency practice resulting from honoring exchange rate guarantees extended prior to August 1988 to development banks, which will automatically expire after maturity of existing commitments (total loans covered by these guarantees amount to about $\$ 20$ million); and (b) certain restrictions relating to Iraq and the Federal Republic of Yugoslavia (Serbia and Montenegro), pursuant to UN Security Council Resolutions, which are subject to notification to the Fund in accordance with Decision 144 (52/51).

Since March 1, 1994, the market rates are determined in an interbank foreign exchange market. On June 30, 2008, the interbank rate of the dinar vis-à-vis the dollar was $\$ 1=$ TD 1.1620, equivalent to SDR 1= TD 1.8983.

\section{Article IV Consultation}

Tunisia is on the 12-month cycle. The last discussions of the Article IV consultation were held in Tunis from May 14 to 28, 2007, and the consultation was concluded by the Executive Board on August 3, 2007.

\section{Technical Assistance}

January 31-February 14, 1996: FAD — assessment of revenue impact of Association Agreement with EU.

March 31-April 4, 1997: STA — introduction of new methodological guidelines according to fifth edition of Balance of Payments Manual.

September 9-12, 1998: MAE—monetary management and development of the money market.

May 11-21, 1999: STA—quarterly national accounts.

May 13-18, 1999: STA-SDDS.

October 12-15, 1999: MAE_-debt management practices.

October 17-27, 2000: STA—quarterly national accounts.

October 25-31, 2000; STA—SDDS meta data finalization.

December 17-21, 2001: MAE_-management of central bank liquidity.

December 12-19, 2003: LEG-AML/CFT. 
May 18-19, 2004: MFD—-technical assistance needs assessment.

July 1-15, 2004: STA—government finance statistics.

January 24-February 5, 2005: FAD—tax policy.

April 7-22, 2005: STA-ROSC, data module.

September 8-21, 2005: FAD_tax administration.

January 16-31, 2006: MFD_FSAP update (mission 1).

March 27-31, 2006: MFD_FSAP update (mission 2).

February 5-15, 2007: MCM-monetary policy.

February 4-7, 2008: LEG-AML/CFT supervisory training of the financial market supervision authority and the stock exchange.

Resident Representative: None 


\section{ANNEX II. FinANCIAL RELATIONS WITH THE WORLD BANK}

(As of July 1, 2008)

1. The World Bank's portfolio in Tunisia has a total of 16 active operations and 120 closed loans, of which 10 International Development Agency (IDA) credits amounting to $\$ 75.2$ million net of cancellations. Cumulative net commitments represent $\$ 5.3$ billion. Of this total, $\$ 4.1$ billion has been repaid. Net commitments for the 16 current operations amount to about $\$ 0.6$ billion.

2. The Country Assistance Strategy (CAS) was approved by the Board on June 3, 2004. It proposes to assist the Government of Tunisia in addressing three key challenges: (a) strengthen the business environment to support the development of a more competitive, internationally integrated private sector and improve competitiveness of the Tunisian economy; (b) enhance skills and employability of graduates and labor force in a knowledge economy; and (c) improve the quality of social services through enhanced efficiency of public expenditures. The CAS progress report was approved by the Board in August 2007. It notes that, while the CAS is overall on track and remains fully relevant for Tunisia's key development challenges, the low level of private investment constitutes a major concern, threatening growth and job creation. A new CAS will be prepared in FY09.

3. Bank lending is a mix of long-term investments in infrastructure and social sector financing, and development policy lending to support reforms at the sectoral and macroeconomic reforms. Recent loan includes an additional financing of $\$ 6.0$ million approved on August 28, 2007 for the Export Development II project to help finance the scaled-up activities associated with increased demand for the second export market access fund. Projects under early stage of preparation are the following: a Water Sector Investment II, an Energy Efficiency, a Community Based Integrated Rural Development project, and an Integration and Competitiveness Development Policy Loan (following the Economic Competitiveness Adjustment Loan IV).

4. Despite the fact that the quality of the portfolio is satisfactory, cumbersome procurement procedures and slow implementation pace are affecting the portfolio performance. An internal portfolio review was undertaken in January 2008. This was followed by a joint update of the 2005 Country Portfolio Performance Review action plan designed to address the key constraints identified and is being implemented jointly by the Bank and counterpart teams. Several procurement workshops are being conducted as part of the action plan.

5. Several Economic and Sector Work (ESW) and technical assistance (TA) outputs to inform and support policy choices and reforms were produced over the last two years. The recent ESW delivered includes a study on Tunisia's Global Integration, identifying reforms to boost growth in services and manufacturing through greater global integration; a report on Employment, Skills Development, and Social Protection; a Small and Medium Enterprise Study on technical centers and industrial land management; and a study on cost assessment of water degradation. Ongoing work includes a Development Policy Review (DPR) that assesses Tunisia's key challenges and policy priorities in the years ahead. This DPR aims at 
providing an analytical basis for the next Country Assistance Strategy (2009) and at providing input to the $11^{\text {th }}$ Plan (2007-11) mid-term review. The Bank is also currently working on a Small and Medium Enterprise Finance Policy Note, a Review of Energy Management Policy, a Water and Wastewater Strategy, and a regional study on the constraints to cross border investment and trade in the Maghreb.

6. Bank's technical assistance activities include: the Tariff Reform and Trade Policy Modeling, the Skill Development/Social Insurance, the Budget Management and Performance Based Budgeting (a multi-year Programmatic Economic and Sector Work), the Development of Logistics Services and Infrastructure, the Assessment of Hospital Performance, the Use of Country Systems in Environment and in Safeguards. 


\section{Tunisia: Financial Relations with the World Bank}

(As of July 1, 2008)

\begin{tabular}{|c|c|c|c|c|c|c|}
\hline & & \multicolumn{3}{|c|}{$\begin{array}{c}\text { Total Net } \\
\text { Commitments }\end{array}$} & \multicolumn{2}{|c|}{$\begin{array}{c}\text { Undisbursed } \\
\text { Balance }\end{array}$} \\
\hline & & \multicolumn{5}{|c|}{ (In millions of dollars) } \\
\hline \multicolumn{7}{|l|}{ IBRD lending operations } \\
\hline 120 loans closed $^{1 /}$ & & & $4,628.1$ & & & \\
\hline \multicolumn{7}{|l|}{16 active loans } \\
\hline \multicolumn{2}{|l|}{-MPT Ozone Depleting Subs. } & \multicolumn{3}{|c|}{5.12} & \multicolumn{2}{|r|}{1.2} \\
\hline \multicolumn{2}{|l|}{-Agric. Support Services } & \multicolumn{3}{|c|}{19.0} & \multicolumn{2}{|r|}{5.6} \\
\hline \multicolumn{2}{|l|}{-GEF Protected Areas Mgmt. } & \multicolumn{3}{|c|}{5.3} & \multicolumn{2}{|r|}{1.4} \\
\hline \multicolumn{2}{|l|}{-Cultural Heritage } & \multicolumn{3}{|c|}{17.0} & \multicolumn{2}{|r|}{10.6} \\
\hline \multicolumn{2}{|l|}{-Transport Sector Invt. II } & \multicolumn{3}{|c|}{37.6} & \multicolumn{2}{|r|}{16.0} \\
\hline \multicolumn{2}{|l|}{-NW Mountainous \& Forestry Areas Devt. } & \multicolumn{3}{|c|}{34.0} & \multicolumn{2}{|r|}{15.9} \\
\hline \multicolumn{2}{|l|}{-Municipal Devt. III } & \multicolumn{3}{|c|}{78.4} & \multicolumn{2}{|r|}{18.3} \\
\hline \multicolumn{2}{|l|}{-Export Development II } & \multicolumn{3}{|c|}{41.8} & \multicolumn{2}{|r|}{22.4} \\
\hline \multicolumn{2}{|l|}{-Education PAQSET II } & & 130.3 & & & 45.7 \\
\hline -ICT Sector Development & & & 13.1 & & & 9.3 \\
\hline -GEF Energy Efficiency Program/Indust. & & & 8.5 & & & 5.9 \\
\hline -GEF Gulf of Gabes & & & 6.3 & & & 5.2 \\
\hline - Urban Water Supply & & & 38.0 & & & 36.0 \\
\hline - Higher Education Reform Support II & & & 76.0 & & & 87.4 \\
\hline - Sustainable Solid Waste Management & & & 22.0 & & & 17.0 \\
\hline - Tunis West Sewerage & & & 66.8 & & & 63.6 \\
\hline Total active loans & & & 599.3 & & & 361.4 \\
\hline $\begin{array}{l}\text { Repayments }{ }^{2 /} \\
\text { Debt outstanding }\end{array}$ & & & $\begin{array}{r}4,083.45 \\
1.604 .7\end{array}$ & & & \\
\hline 2003 & 2004 & 2005 & 2006 & 2007 & 2008 & 2009 \\
\hline $\begin{array}{l}\text { Net lending by the World } \\
\text { Bank (by fiscal year) }\end{array}$ & & & & & & \\
\hline Commitments & 166.3 & 163.1 & 114.0 & 88.8 & 6.0 & 0 \\
\hline Disbursements & 238.6 & 119.4 & 190.7 & 96.88 & 77.0 & 0 \\
\hline Debt service & 305.1 & 303.1 & 301.4 & 417.0 & 301.0 & \\
\hline Principal & 224.8 & 230.5 & 236.4 & 344.7 & 225.3 & 0 \\
\hline Interest $^{5 /}$ & & & & & 75.7 & 0 \\
\hline 82.1 & 80.3 & 72.6 & 65.0 & 72.3 & & \\
\hline Net transfer ${ }^{6 /}$ & -66.5 & -183.7 & -110.7 & -320.1 & -224.0 & 0 \\
\hline
\end{tabular}

1/ Less cancellations, includes adjustment lending, does not include guarantees.

2/ As of July 1, 2008.

3/ Fiscal years start July 1 and end June 30 .

4/ Does not include \$184 million for guarantee on Jorf Lasfar electricity project.

$5 /$ Includes charges.

6/ Equal to disbursement minus debt service. 


\section{ANNEX III. STATISTICAL ISSUES}

1. Economic and financial data are adequate for surveillance. Tunisia subscribed to the SDDS in June 2001 and its metadata are posted on the Dissemination Standards Bulletin Board (DSBB). A data ROSC was published in August 2006, following a mission that took place in April 2005.

\section{Real Sector Statistics}

2. Data on GDP by economic sector are disseminated at current and constant prices. Work is well advanced toward the full adoption of the System of National Accounts 1993 (1993 SNA). Statistical techniques are adequate for the annual accounts but need some refinement for the quarterly estimates. Source data for the quarterly national accounts could be further diversified to improve coverage. Currently, an outdated base year (1990) is used for the constant price series. A new series using 2000 as base year is expected to be released in the near future.

3. Data provided for publication in the International Financial Statistics (IFS) on real sector developments is satisfactory and most data are reported in a timely manner, although export and import price and volume indices are reported with a long lag. Data on employment, unemployment, and wages should be collected and reported on a more frequent basis.

\section{Government Finance Statistics}

4. In addition to the information reported in the SDDS, government finance statistics (GFS) are collected by the staff at the time of the Article IV consultation mission. Regarding data for publication, the annual statement of budgetary central government and consolidated central government operations on a cash basis through 2007 have been reported to STA and are both published in the IFS and Government Finance Statistics Yearbook 2007 and disseminated electronically. The consolidated central government covers budgetary central government, a number of administrative, economic, and social government agencies, and three social security funds. Tunisia does not report monthly or quarterly data for dissemination in the IFS.

\section{External Sector Statistics}

5. Statistics for balance of payments (BOP) and international investment position (IIP) are compiled by the Central Bank of Tunisia (BCT), following the methodology of the fifth edition of the Balance of Payments Manual, (BPM5). The BOP statistics are prepared on a quarterly basis and the IIP on an annual basis, complying with SDDS requirements. However, Tunisia does not report quarterly data for redissemination in IMF publications. The BCT issues preliminary monthly statistics, mostly prepared on the basis of banks' settlements with nonresidents. BOP statistics are generally adequate for annual surveillance, although 
greater detail on the financial account would be desirable. However, the 2005 data ROSC mission noted that remittances of Tunisian workers abroad are classified as income instead of current transfers in national publications (while they are correctly classified in data reported to STA), and that reinvested earnings of foreign direct investments are not recorded in the balance of payments. As an SDDS subscriber, Tunisia reports reserves data following the International Reserves and Foreign Currency Liquidity-Operational Guidelines (Reserves Template) since June 2001.

\section{Monetary and Financial Statistics}

Monetary statistics compiled by the BCT are broadly based on the 1984 Guide to Money and Banking Statistics in International Financial Statistics. Although monetary statistics meet SDDS requirements, there is room for improvement. For example, according to the findings of the data ROSC mission of April 2005, banks' claims on the rest of domestic sector (other than central government and financial corporations) are not fully sectorized and monetary gold is not valued at the current market price. The BCT has initiated a plan to migrate to the methodology recommended in the Monetary and Financial Statistics Manual (2000). The BCT reported to STA test data on the Standardized Report Form for central bank (Form 1SR) for December 2004 and October 2005. To facilitate publication in the International Financial Statistics-Supplement, the BCT needs to report to STA the Standardized Report Forms (at least forms $1 \mathrm{SR}, 2 \mathrm{SR}$, and 5SR) on a regular monthly basis.

Tunisia is one of the countries that participated in the pilot coordinated compilation exercise for financial soundness indicators (FSIs) conducted by STA. Tunisia's FSI data as of end2005 along with metadata are now available to the public through the Fund's website (http://www.imf.org/external/np/sta/fsi/part.asp?iso=TUN). 
Table of Common Indicators Required for Surveillance

AS OF JULY 10, 2008

\begin{tabular}{|c|c|c|c|c|c|c|c|}
\hline & & & & Frequency & Freauncy & Memo Items: & \\
\hline & $\begin{array}{c}\text { latest } \\
\text { observation }\end{array}$ & received & $\begin{array}{c}\text { of } \\
\text { Data }^{7}\end{array}$ & $\begin{array}{c}\text { of } \\
\text { Reporting }^{7}\end{array}$ & $\begin{array}{c}\text { of } \\
\text { Publication }\end{array}$ & $\begin{array}{l}\text { Data Quality - } \\
\text { Methodological } \\
\text { soundness }^{8}\end{array}$ & $\begin{array}{l}\text { Data Quality - } \\
\text { Accuracy and } \\
\text { reliability }\end{array}$ \\
\hline Exchange Rates & Current & Current & $\mathrm{D}$ & $\mathrm{D}$ & $\mathrm{D}$ & & \\
\hline $\begin{array}{l}\text { International Reserve Assets and } \\
\text { Reserve Liabilities of the Monetary } \\
\text { Authorities }^{1}\end{array}$ & May 2008 & Jun. 2008 & M & M & M & & \\
\hline Reserve/Base Money & May 2008 & $6 / 17 / 08$ & M & $\mathrm{M} / \mathrm{W}$ & M & \multirow{4}{*}{$\mathrm{LO}, \mathrm{O}, \mathrm{LO}, \mathrm{LO}$} & \multirow{4}{*}{$\begin{array}{l}\mathrm{LO}, \mathrm{O}, \mathrm{O}, \mathrm{O} \\
\text { LO }\end{array}$} \\
\hline Broad Money & Apr. 2008 & $6 / 17 / 08$ & M & $\mathrm{M} / \mathrm{W}$ & M & & \\
\hline Central Bank Balance Sheet & May 2008 & $6 / 17 / 08$ & M & $\mathrm{M} / \mathrm{W}$ & M & & \\
\hline $\begin{array}{l}\text { Consolidated Balance Sheet of the } \\
\text { Banking System }\end{array}$ & Apr. 2008 & $6 / 17 / 08$ & M & Q & Q & & \\
\hline Interest Rates ${ }^{2}$ & Current & Current & $\mathrm{D}$ & $\mathrm{D}$ & $\mathrm{D}$ & & \\
\hline Consumer Price Index & June 2008 & $7 / 19 / 08$ & M & $\mathrm{M} / \mathrm{W}$ & M & & \\
\hline $\begin{array}{l}\text { Revenue, Expenditure, Balance and } \\
\text { Composition of Financing }{ }^{3}- \\
\text { General Government }^{4}\end{array}$ & 2007 & Mar. 2008 & A & A & A & \multirow{2}{*}{$\mathrm{LO}, \mathrm{LO}, \mathrm{LO}, \mathrm{O}$} & \multirow{2}{*}{$\begin{array}{l}\mathrm{O}, \mathrm{O}, \mathrm{O}, \mathrm{O} \\
\quad \mathrm{LO}\end{array}$} \\
\hline $\begin{array}{l}\text { Revenue, Expenditure, Balance and } \\
\text { Composition of Financing }{ }^{3}-\text { Central } \\
\text { Government }\end{array}$ & Apr. 2008 & June 2008 & M & M & I & & \\
\hline $\begin{array}{l}\text { Stocks of Central Government and } \\
\text { Central Government-Guaranteed } \\
\text { Debt }^{5}\end{array}$ & Q4 2007 & Feb. 2008 & Q & Q & Q & & \\
\hline External Current Account Balance & Q1 2008 & May 2008 & Q & $\mathrm{Q} / \mathrm{W}$ & Q & \multirow[b]{2}{*}{ LO, O, LO, LO } & \multirow{2}{*}{$\begin{array}{l}\mathrm{O}, \mathrm{O}, \mathrm{O}, \mathrm{O} \\
\quad \mathrm{LO}\end{array}$} \\
\hline $\begin{array}{l}\text { Exports and Imports of Goods and } \\
\text { Services }\end{array}$ & Q1 2008 & May 2008 & Q & Q & Q & & \\
\hline GDP/GNP & Q4 2007 & Apr. 2008 & Q & $\mathrm{Q} / \mathrm{W}$ & Q & $\begin{array}{l}\text { LO, O, LNO, } \\
\text { LNO }\end{array}$ & $\begin{array}{l}\text { LO, O, LO, O, } \\
\text { LNO }\end{array}$ \\
\hline Gross External Debt & Q4 2007 & Mar. 2008 & A & A & A & & \\
\hline International Investment Position ${ }^{6}$ & 2007 & Jun. 2008 & A & A & M & & \\
\hline
\end{tabular}

${ }^{1}$ Includes reserve assets pledged or otherwise encumbered as well as net derivative positions.

${ }^{2}$ Both market-based and officially determined, including discount rates, money market rates, rates on treasury bills, notes and bonds.

${ }^{3}$ Foreign, domestic bank, and domestic nonbank financing.

${ }^{4}$ The general government consists of the central government (budgetary funds, extra budgetary funds, and social security funds) and state and local governments.

${ }^{5}$ Including currency and maturity composition.

${ }^{6}$ Includes external gross financial asset and liability positions vis-à-vis nonresidents.

${ }^{7}$ Daily (D), weekly (W), monthly (M), quarterly (Q), annually (A), irregular (I); and not available (NA).

${ }^{8}$ Reflects the assessment provided in the data ROSC Substantive Update (published on August 7, 2006, and based on the findings of the mission that took place during April 7-22, 2005) for the dataset corresponding to the variable in each row. The assessment indicates whether international standards concerning concepts and definitions, scope, classification/sectorization, and basis for recording are fully observed $(\mathrm{O})$; largely observed (LO); largely not observed (LNO); not observed (NO); and not available (NA).

${ }^{9}$ Same as footnote 7, except referring to international standards concerning (respectively) source data, assessment of source data, statistical techniques, assessment and validation of intermediate data and statistical outputs, and revision studies. 


\section{IMF Executive Board Concludes 2008 Article IV Consultation with Tunisia}

On August 6, 2008, the Executive Board of the International Monetary Fund (IMF) concluded the Article IV consultation with Tunisia. ${ }^{1}$

\section{Background}

Tunisia's sound economic policies and pragmatic approach to structural reforms continue to bear fruit, as evidenced by strong growth and improved social indicators. Real GDP growth averaged 5 percent a year while the macroeconomic and financial position strengthened substantially during the past decade.

Tunisia has so far weathered relatively well the difficult international environment. Real GDP growth increased from 5.5 percent in 2006 to 6.3 percent in 2007-a record over the last decade - underpinned by strong performance of agriculture, energy, manufacturing and the services sectors. On the demand side, vigorous exports and investment powered the growth acceleration. Inflation has picked up, due mainly to rising international fuel and food prices and, to a lesser extent, growing liquidity in the banking system reflecting increasing foreign direct investment (FDI). Year-onyear inflation reached 6 percent in April 2008 before pulling back to 4.9 percent in June 2008. The Central Bank of Tunisia (BCT) responded by tightening monetary policy starting in the second half of 2007.

\footnotetext{
${ }^{1}$ Under Article IV of the IMF's Articles of Agreement, the IMF holds bilateral discussions with members, usually every year. A staff team visits the country, collects economic and financial information, and discusses with officials the country's economic developments and policies. On return to headquarters, the staff prepares a report, which forms the basis for discussion by the Executive Board. At the conclusion of the discussion, the Managing Director, as Chairman of the Board, summarizes the views of Executive Directors, and this summary is transmitted to the country's authorities.
} 
The fiscal deficit was kept within the 2007 budget target of 3 percent of GDP. Revenue exceeded expectations owing mainly to stronger oil revenue-notably from oil companies' higher profits due to surging oil prices and increased domestic production. The additional revenue offset expenditure overruns mainly caused by rising direct food and fuel subsidies. Continued fiscal consolidation and privatization receipts further reduced public debt-to-GDP ratio to about 51 percent at end-2007.

The current account deficit widened due to declining terms of trade, but the significant increase in FDI inflows increased reserves to over $\$ 81 / 2$ billion, largely sufficient to cover short-term liabilities.

Bank performance improved significantly in 2007, including banking activity, profitability, and prudential indicators. The ratio of nonperforming loans (NPLs) to total loans declined from 24 percent in 2003 to 17.3 percent in 2007, largely accounted for by the proactive management of such claims, while the provisions-to-NPLs ratio increased from 43.1 percent to 53.8 percent.

The short-term outlook is encouraging despite the challenging international environment. In 2008, real GDP growth is projected to decelerate moderately to 5.5 percent. Inflation would remain around 5 percent if international prices taper off and monetary policy continues to be restrictive. High fuel and food prices are expected to widen the current account deficit to 3.5 percent of GDP. The fiscal deficit is projected to remain at 3 percent of GDP, owing to buoyant revenue, notably from the hydrocarbon sector. The medium-term outlook remains favorable with growth projected at above 6 percent sustained by strong FDI. Risks to the outlook are essentially related to the international environment.

\section{Executive Board Assessment}

Directors commended the authorities for the notable resilience and continued strong performance of the Tunisian economy, which has been founded on prudent and forward-looking economic policies and market-oriented structural reforms. The outlook remains favorable, with buoyant FDI supporting growth, although there are downside risks related mostly to the global economic turbulence. Directors considered that the key immediate challenge confronting the authorities will be to address the pressures arising from the global food and fuel price increases while maintaining macroeconomic sustainability. Over the medium term, employment creation and income growth will be key to improving economic welfare in Tunisia.

Directors commended the authorities' commitment to fiscal prudence, which will remain essential for lowering the public debt. They endorsed the authorities' decision to contain the fiscal deficit within the 2008 budget target, which will require tight control over current spending and likely additional adjustments to domestic petroleum prices. They noted that buoyant fiscal revenues, particularly from the hydrocarbon sector, have accommodated the gradual passthrough of international oil and food price increases to domestic prices under the current subsidy system. Directors noted, however, that the current subsidy system is not sustainable, and suggested its replacement with a targeted safety net for the most vulnerable groups that would better support medium-term fiscal sustainability, reduce the country's vulnerability to shocks, and create the fiscal space for additional social and infrastructure expenditures. In this context, they welcomed the authorities' intention in the $\mathrm{XI}^{\text {th }}$ Plan to phase out subsidies for petroleum products by 2011 and to ensure better control of expenditures for food subsidies. 
Directors supported the restrictive monetary stance of the BCT. They recommended that the authorities stand ready to increase the BCT's key policy interest rate if inflationary pressures intensify, given that growth still has significant momentum. They supported the BCT's efforts to manage persistent excess liquidity in the financial system, and to continue to build an inflationtargeting framework for monetary policy.

Directors considered that the exchange rate of the Tunisian dinar is broadly aligned with fundamentals and that the authorities' policies are consistent with external stability. Some Directors saw merit in an accelerated transition toward the authorities' commendable objectives of a floating exchange rate and an inflation-targeting framework.

Directors welcomed the continued strengthening of the banking sector's performance, with greater profitability, a decline in nonperforming loans, and improved loan-loss provisioning. Further strengthening of the banking sector should remain a high priority as the authorities continue to gradually open up the capital account. They welcomed the potential growth and employment benefits of the large FDI-financed projects, but counseled prudence with respect to real estate projects in particular, which may create a credit risk for the banking sector and contingent liabilities for the government. Directors supported the authorities' objective of implementing the Basel II system by end-2009 and achieving full compliance with international AML/CFT standards over the medium term.

Directors welcomed the steps being taken by the authorities to deepen the global and regional integration of the Tunisian economy. They praised the authorities for their pragmatic approach to trade and financial integration, and noted the recent important milestone of achieving bilateral free trade in industrial goods with the European Union. They looked forward to further simplification and reduction of tariffs on a most-favored-nation basis.

Directors welcomed the steps aimed at further improving the business climate. They looked forward to further progress in liberalizing the services sector and reforming the tax and customs administration, in order to promote domestic and foreign investment.

Public Information Notices (PINs) form part of the IMF's efforts to promote transparency of the IMF's views and analysis of economic developments and policies. With the consent of the country (or countries) concerned, PINs are issued after Executive Board discussions of Article IV consultations with member countries, of its surveillance of developments at the regional level, of post-program monitoring, and of ex post assessments of member countries with longer-term program engagements. PINs are also issued after Executive Board discussions of general policy matters, unless otherwise decided by the Executive Board in a particular case. 
Table 1. Tunisia: Selected Economic Indicators, 2003-08

(Quota: SDR 286.5 million)

(Population: 10.2 million; 2007)

(Per capita GDP: $\$ 3,594 ; 2007$ )

(Poverty rate: 3.8 percent; 2005)

(Main export: textiles, electronic and mechanical goods, energy, tourism; 2007)

\begin{tabular}{|c|c|c|c|c|c|c|}
\hline & 2003 & 2004 & 2005 & 2006 & $\begin{aligned} 2007 \\
\text { Prel. }\end{aligned}$ & $\frac{2008}{\text { Proj. }}$ \\
\hline Output and Prices & \multicolumn{6}{|c|}{ (Annual percentage change) } \\
\hline Real GDP (market price) & 5.6 & 6.0 & 4.0 & 5.5 & 6.3 & 5.5 \\
\hline Consumer prices (end of period) & 4.5 & 1.2 & 3.7 & 3.3 & 5.3 & 4.7 \\
\hline Consumer prices (period average) & 2.7 & 3.6 & 2.0 & 4.5 & 3.1 & 5.1 \\
\hline Investment and Saving & \multicolumn{6}{|c|}{ (In percent of GDP) } \\
\hline Gross capital formation & 25.0 & 24.5 & 22.0 & 24.1 & 25.1 & 25.1 \\
\hline Of which: Nongovernment $1 /$ & 17.8 & 17.5 & 15.6 & 17.9 & 19.1 & 18.8 \\
\hline Gross national savings & 22.1 & 22.5 & 20.8 & 22.1 & 22.4 & 21.6 \\
\hline Of which: Nongovernment $1 /$ & 18.0 & 18.0 & 17.5 & 18.9 & 19.5 & 18.1 \\
\hline Public Finances 2/ & \multicolumn{6}{|c|}{ (In percent of GDP) } \\
\hline Revenue, excluding grants and privatization & 23.7 & 23.8 & 23.6 & 23.8 & 24.2 & 24.6 \\
\hline Expenditure and net lending & 27.1 & 26.6 & 26.9 & 26.6 & 27.2 & 27.6 \\
\hline Budget balance, excluding grants and privatization & -3.4 & -2.8 & -3.2 & -2.9 & -3.0 & -3.0 \\
\hline Primary balance, excluding grants and privatization & -0.6 & 0.0 & -0.4 & -0.1 & -0.3 & -0.5 \\
\hline Total government debt & 60.5 & 59.4 & 58.3 & 53.9 & 50.9 & 47.0 \\
\hline Monetary Sector & \multicolumn{6}{|c|}{ (Annual percentage change, unless otherwise indicated) } \\
\hline Credit to the economy & 4.6 & 5.3 & 6.3 & 6.6 & 9.6 & 8.5 \\
\hline Base money & 5.5 & 12.2 & 21.9 & 17.6 & 15.3 & 19.7 \\
\hline Broad money & 6.3 & 10.3 & 11.0 & 11.4 & 12.5 & 10.5 \\
\hline Velocity of broad money & 1.7 & 1.6 & 1.6 & 1.6 & 1.5 & 1.5 \\
\hline Three-month treasury bill rate (period average, in percent) $3 /$ & 5.5 & 5.1 & 5.1 & 5.1 & 5.1 & 5.1 \\
\hline External Sector & \multicolumn{6}{|c|}{ (In percent of GDP, unless otherwise indicated) } \\
\hline Exports of goods (in $\$$, percentage change) & 17.1 & 20.7 & 8.3 & 9.7 & 30.4 & 29.9 \\
\hline Imports of goods (in \$, percentage change) & 14.7 & 17.6 & 2.9 & 12.7 & 28.0 & 29.1 \\
\hline Merchandise trade balance & -9.1 & -8.6 & -6.8 & -8.2 & -8.4 & -9.4 \\
\hline Current account excluding official transfers & -2.9 & -1.9 & -1.1 & -2.0 & -2.6 & -3.5 \\
\hline Current account including official transfers & -2.7 & -1.6 & -0.7 & -1.5 & -2.2 & -3.3 \\
\hline Foreign direct investment 4 / & 2.1 & 2.1 & 2.6 & 3.1 & 4.2 & 4.6 \\
\hline Total external debt & 66.8 & 66.5 & 65.4 & 58.3 & 54.9 & 51.8 \\
\hline Gross reserves (in billions of dollars) $5 /$ & 3.0 & 4.0 & 4.4 & 6.8 & 7.9 & 8.9 \\
\hline In months of next year imports of goods and services & 2.5 & 3.1 & 3.3 & 4.0 & 3.5 & 3.6 \\
\hline $\begin{array}{l}\text { In percent of short-term external debt (on remaining } \\
\text { maturity basis) }\end{array}$ & 61.8 & 82.2 & 88.3 & 137.1 & 137.7 & 133.9 \\
\hline \multicolumn{7}{|l|}{ Memorandum Items: } \\
\hline Nominal GDP (in \$ billions) & 26.6 & 29.3 & 27.6 & 31.8 & 36.7 & 40.2 \\
\hline Unemployment rate (in percent) & 14.3 & 13.9 & 14.2 & 14.3 & 14.1 & 14.0 \\
\hline Net imports of petroleum products (in millions of dollars) & 328.8 & 399.0 & 393.4 & 632.1 & -106.3 & 108.9 \\
\hline Local currency per dollar (period average) & 1.3 & 1.2 & 1.3 & 1.3 & 1.3 & $\ldots$ \\
\hline Real effective exchange rate (annual average, percentage change) & -5.0 & -3.5 & -4.6 & -0.8 & -2.9 & $\ldots$ \\
\hline Stock market index 6/ & $1,250.2$ & $1,331.8$ & $1,615.1$ & $2,331.1$ & $2,614.1$ & $3,075.4$ \\
\hline
\end{tabular}

Sources: Tunisian authorities and Fund staff estimates.

$1 /$ Includes public enterprises.

$2 /$ the fiscal year is the calendar year.

$3 / \ln 2008$, average for the first four months.

$4 /$ in 2006, excludes receipts from the privatization of Tunisie Télécom, of about \$2.2 billions.

$5 /$ in 2006 includes receipts from the privatization of Tunisie Télécom.

6/ TUNINDEX (1000=4/1/1998). The 2008 data as of August 8, 2008. 


\title{
Statement by Mohammad Mojarrad \\ Executive Director for Tunisia
}

August 6, 2008

We thank staff for their well-focused report and convey our Tunisian authorities' appreciation for the continuous excellent cooperation with the Fund.

\begin{abstract}
Directors may recall that last year's consultation was centered on the authorities' medium-term strategy for the period 2007-2011. Staff's main recommendations for the success of this strategy, in the context of the ongoing integration into the world economy, are to maintain fiscal consolidation, strengthen the monetary and exchange rate framework, and to address the remaining weaknesses in the financial system to enhance the economy's flexibility and resilience.
\end{abstract}

The 2008 Article IV consultation was appropriately focused on the immediate risks to the short-term outlook from rising fuel and food prices. It would allow staff and, hopefully, the Board after today's discussion to recognize the authorities' growing ability to better manage emerging risks without deviating from their medium-term objectives of further improving employment and living standards while safeguarding financial stability, and to confirm the economy's resilience to shocks.

The authorities agree with staff conclusion that Tunisia has so far weathered relatively well the difficult international environment. In 2007, GDP growth accelerated to 6.3 percent, the budget deficit was kept at 3 percent, and the debt and financial sector indicators were further improved. However, Tunisia, like many other countries, observed a pick-up in inflation due to the rise in international fuel and food prices.

In the area of fiscal policy, the authorities will continue to be guided by the objective of converging public debt indicators to emerging market economies standard. Thus, in spite of the sharp rise in commodities and fuel prices, the authorities intend to keep the fiscal deficit within the 2008 budget target of 3 percent.

In the energy sector, the authorities have been implementing since 2006 a comprehensive strategy centered on regular increase in domestic petroleum retail prices (more than doubling since 2003), proactive substitution policy to encourage the use of alternative and renewable energy, introduction of a mandatory energy audit in the industrial sector to promote efficiency, and extensive public awareness campaigns focused on the importance of energy conservation and the burden of energy subsidies on the budget. These efforts, coupled with an increase in production, are paying off, with subsidies stabilizing 
around 1 percent of GDP in the last three years and the energy trade balance moving to surplus in 2007. Barring further deterioration in the international oil markets, the authorities remain committed to phasing out petroleum subsidies by 2011.

With regard to food subsidies, the authorities made a deliberate decision to refrain from implementing the annual price adjustments so as to facilitate public acceptance of the successive adjustments of petroleum prices and preserve social stability. They agree with staff that the level of subsidies is not sustainable and are working on a medium-term reform program to better rationalize subsidies and reduce its burden on the budget. In this connection, the authorities have already stepped up controls and targeting of subsidies and implementation of policies to promote agricultural production. The authorities look forward to Board consideration of the FAD paper on Government Subsidies-Agenda for Future Reforms.

The Central Bank of Tunisia (BCT) is carefully following price developments and is pursuing a tight monetary stance since mid-2007. The BCT considers that the two recent increases in reserves requirements are producing their intended effect. After peaking at 6 percent in April 2008, year-on-year inflation has been on a declining trend in May and June (5.3 and 4.9 percent, respectively). For 2008, staff project inflation to stabilize around 5 percent. The BCT will continue to adopt a tight bias in the conduct of monetary policy to better control excess liquidity and to keep inflation under control; it does not exclude increasing its policy rate, if circumstances warrant.

The BCT concurs with staff assessment that the exchange rate of the dinar is broadly aligned with its fundamentals, and the authorities' policies are consistent with external stability. In this connection, the authorities appreciate the workshop organized by staff on the CGER methodologies to estimate equilibrium real exchange rate. Going forward, the BCT will pursue its gradual move toward inflation targeting, floating exchange rate, and capital account liberalization.

The authorities are confident that their strategy to improve soundness of the banking sector is on track. The dual objectives for 2009 to reduce NPLs to 15 percent of total loans and increase the ratio of provisions to NPLs to 70 percent, which is broadly in line with the recommendations of the FSAP update, is within reach after the significant progress achieved since 2003. The authorities agree with staff that the level of NPLs is still relatively high. They are working with interested banks to set up restructuring plans to boost their capital base and are happy to report that Société Générale has agreed to participate in a significant restructuring of its subsidiary (Union Internationale de Banques) that will address the bank's capital needs and allow it to be in conformity with all regulatory ratios. 
Other reforms and initiatives relevant for the 2008 Article IV consultation:

- Entry into force of the Association Agreement with the EU;

- Adoption of a new customs code;

- Establishment of a Large Taxpayer Unit;

- Privatization of the Banque Tuniso-Koweitienne;

- Completion of the AML/CFT evaluation by MENA FATF and publication of the report;

- Finalization of the FSIs metadata under the coordinated compilation exercise. 